OPEN ACCESS

Edited by: Basilios Tsikouras, Universiti Brunei Darussalam, Brunei

Reviewed by: Antonio Pedrera, Instituto Geológico y Minero de España (IGME), Spain Sergio Llana-Fúnez, University of Oviedo, Spain

*Correspondence: Mongkol Udchachon mongkol.c@msu.ac.th

Specialty section: This article was submitted to Structural Geology and Tectonics, a section of the journa

Frontiers in Earth Science

Received: 07 September 2020 Accepted: 07 April 2021 Published: 28 May 2021

Citation:

Burrett C, Udchachon M and Thassanapak H (2021) The Truong Son, Loei-Phetchabun, and Kontum Terranes in Indochina: Provenance, Rifting, and Collisions. Front. Earth Sci. 9:603565. doi: 10.3389/feart.2021.603565

\section{The Truong Son, Loei-Phetchabun, and Kontum Terranes in Indochina: Provenance, Rifting, and Collisions}

\author{
Clive Burrett ${ }^{1}$, Mongkol Udchachon ${ }^{1,2 *}$ and Hathaithip Thassanapak ${ }^{2}$ \\ ${ }^{1}$ Palaeontological Research and Education Centre, Mahasarakham University, Mahasarakham, Thailand, ${ }^{2}$ Applied \\ Palaeontology and Biostratigraphy Research Unit, Department of Biology, Faculty of Science, Mahasarakham University, \\ Mahasarakham, Thailand
}

The three main regions of Indochina are defined as the Truong Son, Loei-Phetchabun, and Kontum terranes. The aim of this review is to integrate numerous petrological studies with sedimentary, palaeontological, and provenance studies in order to construct a preliminary tectonic model which shows the terranes docked in the earliest Carboniferous (Truong Son with Loei-Phetchabun) and in the Permian (Kontum). The Kontum Terrane is characterized by Proterozoic magmatism, mid-Ordovician to Early Devonian granites, and Permian charnockites. Major carbonate platforms developed in the Givetian to earliest Tournaisian on Truong Son and from the Visean to mid-Permian across Truong Son and Loei-Phetchabun terranes. The Truong Son has Silurian granites and a Late Ordovician to Silurian magmatic arc along its southern and western borders caused by subduction of oceanic lithosphere, the remnants of which are now partially preserved in the Loei and Tamky sutures. A region to the east of the Loei Suture in the Loei Foldbelt has a similar-age volcanic arc extending northwards into Laos and is included in Truong Son. A platform-margin coral-stromatoporoid reef developed on Truong Son in the Frasnian and was coincident with a gap in magmatism until the Pennsylvanian with granite magmatism became widespread until the Late Triassic. In the Loei-Phetchabun Terrane, Devonian siliciclastics, volcanics are overlain by Givetian limestones and patch reefs and in turn overlain by Late Devonian to earliest Tournaisian radiolarian cherts and siliciclastics. Tournaisian to early Visean siliciclastic turbidites were coincidental with initial uplift and deformation and were replaced by Visean terrestrial evaporites and coal and marine limestones. Arc magmatism along the Loei-Phetchabun Terrane indicates intermittent eastward subduction from mid-Devonian to mid-Triassic. Carboniferous-Triassic volcanism extends eastward along the northern margin of Cambodia and is probably an extension of Loei-Phetchabun. Ordovician within-plate basalts in Kontum and the transition from shallow marine Ordovician siliciclastics to Silurian deep-marine sediments and a volcanic arc in Truong Son suggest rifting of both terranes from Gondwana in the Late Ordovician. Initial docking of Truong Son with South China was probably in the late Silurian to Early Devonian and docking of Loei-Phetchabun and Truong Son was in the late Tournaisian to early Visean.

Keywords: tectonics, Indochina, Laos, Vietnam, Thailand, palaeogeography, Loei Fold Belt, Truong Son Terrane 


\section{INTRODUCTION}

In the 1980's mainland Southeast Asia was divided geologically into two main terranes, Shan-Thai and Indochina, separated by the ophiolitic Nan Suture (Bunopas, 1982). Shan-Thai was later incorporated into the geographically more extensive Sibumasu Terrane concept (Metcalfe, 1984). Bunopas (1982) proposed that Shan-Thai (part of Sibumasu) rifted from the Australian sector of Gondwana in the Early Permian and collided with Indochina in the Late Triassic causing at least one phase of the Indosinian orogeny. A major distinction between Sibumasu and Indochina was regarded as the presence of early Permian glacimarine sediments and faunas on Sibumasu and the coeval tropical carbonates and faunas on Indochina. The subsequent recognition of Permo-Carboniferous tropical marine faunas in part of northern Thailand, closely associated with basalts and deep-water sediments, led to the introduction and definition of the Inthanon Terrane (Barr et al., 1990; Barr and MacDonald, 1991; Ueno and Charoentitirat, 2011; Metcalfe, 2021) with the Mae Yuam Fault Zone (MYFZ on Figure 1) forming its western boundary and the Permo-Triassic volcanic arc Sukhothai Terrane forming its eastern boundary (SU on Figure 1).

The Indochina Block/Terrane was perhaps unfortunately named, as the geographic concept of Indochina originally embraced the whole Southeast Asian mainland culturally influenced by both India and China. Later the French term Indochine was restricted to the former French colonies now known as Vietnam, Laos, and Cambodia. In this paper we refer to Indochina in its tectonic sense rather than its geographic sense. This restricted tectonic usage is close to the French colonial term Indochine (including Cambodia, Laos, and Vietnam) but excludes northeast Vietnam and includes large parts of northeastern Thailand (Figure 1).

The term Annamia was proposed by Torsvik and Cocks (2009) and Cocks and Torsvik (2013) as a potentially attractive alternative to geological Indochina but the term is somewhat misleading and geographically too extensive as the Annamite Cordillera is contained only within the Truong Son Terrane, the French colony of Annam was limited to the mainly coastal central Vietnam area between Tonkin and Cochinchine and the term annamite was sometimes used as an ethnic slur (www.owlapps.net).

Prior to 1950, geological work in mainland South East Asia was mainly carried out by staff of the colonial geological surveys of French Indochina, Burma (British India) and Malaya and some from local university academics and international visitors. Many areas were unexplored or very poorly known geologically. Although the Royal Thai Department of Mines and Geology was established in 1891 little was known about Thai geology outside of Thailand until the publication of the first compilation of the geology of Thailand in English in 1951 with the help of the United States Geological Survey (Brown, 1951). The Geological Survey of Indochina was established as a branch of the Department of Agriculture and Commerce in Hanoi in 1898 (Genovese, 2011) and prior to 1970, major contributions to mapping and research were made, for example, by Mansuy, Deprat, Colani, Dussault, Hoffet, Gubler, Bourret,
Saurin, Fromaget, and Fontaine. Thick vegetation and a lack of infrastructure along with wars, genocide, and insurgencies delayed intensive geological research until the 1980's. However, unexploded ordnance still remains a problem in many areas. In the last 30 years considerable advances have been made by the national geological surveys and universities of Cambodia, Laos, Thailand, and Vietnam as well as by academic, government, and company geologists and paleontologists from many countries. Many areas were and still are unexplored or very poorly known geologically.

Much of the recent work in the Indochina region has been petrological, geochemical, and geochronological particularly on plutonic, volcanic, and metamorphic rocks and associated ore deposits (e.g., Khin et al., 2014). There have been few studies on the structural geology of the Palaeozoic to Triassic in Indochina [other than for example Findlay (1997), Findlay and Trinh (1997), Lepvrier et al. (1997, 2004, 2008), Morley et al. (2013), Tran et al. (2014), and Faure et al. (2018)] and little basic structural work has been carried out during regional geological mapping which has often led to gross overestimates of formation thicknesses (e.g., Ban et al., 2000a,b).

As our work has concentrated on sedimentary sequences and their contained faunas, we will attempt to integrate these numerous petrological studies with work on sedimentary, palaeontological, and provenance studies in order to construct a preliminary tectonic model for the region which identifies three terranes that docked in the earliest Carboniferous (Truong Son with Loei-Phetchabun) and in the Permian (Kontum). Although many geoscientists continue to regard the Indochina Terrane/Block as unitary for pre-Permian time (e.g., Yan et al., 2020; Metcalfe, 2021) here we follow Mouret (1994), Lepvrier et al. (1997, 2004, 2008), Burrett et al. (2014a), Khin et al. (2014), Lai et al. (2014), Tran et al. (2014), and Tri et al. (2020) in recognizing Indochina as a composite formed by the amalgamation of three or more terranes during the Palaeozoic. Regarding Indochina as a unitary block in the pre-Visean can no longer be maintained (Figure 1). Tri (1977) was the first to name and emphasize the tectonic importance of the Tamky Suture in central Vietnam (TKS on Figure 1) which led the way to the theoretical disassembling of the unitary Indochina Block.

\section{TERRANE DEFINITIONS AND CONSTITUENT TERRANES OF INDOCHINA}

\section{Terrane Definitions}

The terrane concept has been useful in non-genetic descriptions of the subdivisions of complex orogenic belts and aiding in the decipherment of their amalgamation (Howell, 1980, 1989; Howell et al., 1985; Howell and Howell, 1995; Badarch et al., 2002). Terranes have distinctive geological histories and are generally bounded by faults, sutures, or major geological discontinuities. They may or may not be far-traveled. The terrane concept replaces, at least partially, many ambiguous or loosely defined terms, often genetic and often derived from geosynclinal theory, such as massif, block, fold belt, craton, eugeosyncline, geanticline, etc. 


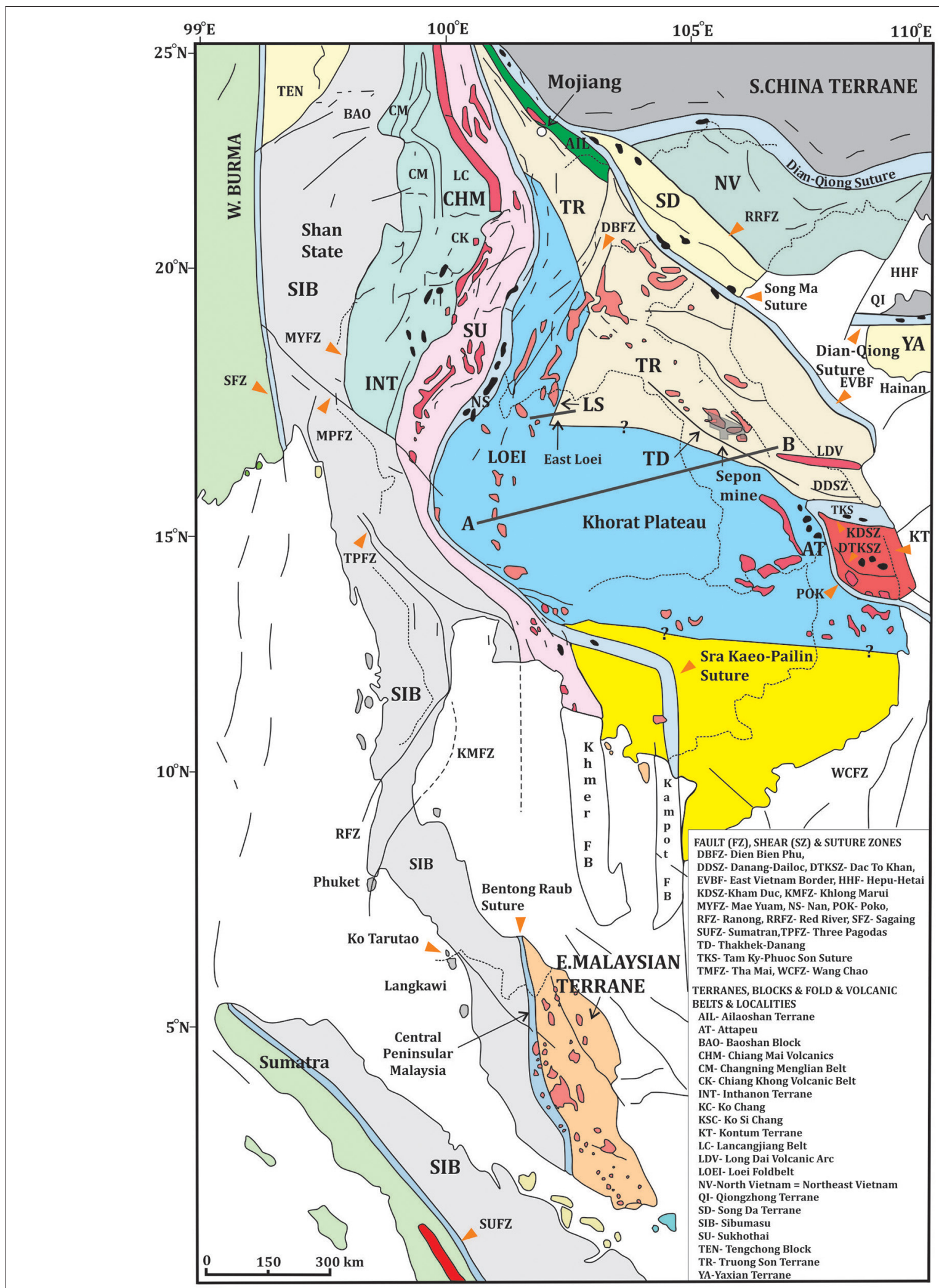

FIGURE 1 | Map of terranes in mainland Southeast Asia. Blue = Loei-Phetchabun Terrane, TR = Truong Son Terrane, Red = KT, Kontum Terrane. Line A-B is line of geological section shown in Figure 3. TKS, Tamky Suture; LDV, Long Dai Volcanic Arc (latest Ordovician to Silurian). The debatable extension of the Truong Son 
FIGURE 1 | Terrane northwest into Yunnan (China) is based on the existence of widespread Silurian strata which is typical of the Truong Son Terrane rather than the Loei-Phetchabun Terrane (Loydell et al., 2019). The extent of the Loei-Phetchabun and Truong Son terranes under the Mesozoic terrestrial siliciclastics of the Khorat Group on the Khorat Plateau is highly speculative due to a lack of petroleum wells that have penetrated the "mid"-Carboniferous unconformity which is picked on several seismic sections [see Booth and Sattayarak (2011)]. Their extent shown in Figure $\mathbf{1}$ is, however, plausible based on seismic and other geophysical data (Figure 3). The extension of the Loei Suture eastwards through Cambodia is based on Cheng et al. (2019), Khin et al. (2014), and Udchachon et al. (2018). The extension of the Sra Kaeo-Pailin Suture through Cambodia is based on Udchachon et al. (2018). Note that much of Cambodia is terra incognita geologically and the area in southern Cambodia colored yellow is not assigned to a terrane. Map adapted from Burrett et al. (2014a) and Loydell et al. (2019).

TABLE 1 | Table summarizing main characteristics of each of the Indochina terranes.

\begin{tabular}{|c|c|c|}
\hline Loei-Phetchabun Terrane & Truong Son Terrane & Kontum Terrane \\
\hline $\begin{array}{l}\text { Devonian to Tournaisian consists mainly of } \\
\text { siliciclastics, volcaniclastics and radiolarian cherts } \\
\text { and minor limestones. } \\
\text { Givetian patch reefs. } \\
\text { No major pre- Carboniferous carbonate platform } \\
\text { Absence of extensive regional high } \\
\text { grade metamorphism. }\end{array}$ & $\begin{array}{l}\text { Ordovician-Silurian arc volcanics and granitoids. } \\
\text { Ordovician siliciclastics with minor limestone. } \\
\text { Widespread Silurian sedimentation. } \\
\text { Major mainly carbonate platform from reef- fringed } \\
\text { Frasnian to earliest Visean. } \\
\text { South China fish fauna from Early Devonian. } \\
\text { Absence of extensive regional high } \\
\text { grade metamorphism. }\end{array}$ & $\begin{array}{l}\text { Proterozoic-Ordovician granitoid magmatism. } \\
\text { Ordovician Volcanic Arc Granites and Ord-Silurian } \\
\text { metamorphism from } 460 \text { to } 420 \mathrm{Ma} \\
\text { Ordovician-Silurian within plate basaltic } \\
\text { amphibolites. } \\
\text { Permian c. } 250 \mathrm{Ma} \text { charnockites. } \\
\text { Extensive Triassic regional high-low grade } \\
\text { metamorphism from } 245 \text { to } 230 \mathrm{Ma}\end{array}$ \\
\hline
\end{tabular}

\section{Loei-Phetchabun Terrane}

The Loei-Phetchabun Terrane extends from the Loei Province in NE Thailand along the western (Phetchabun Province) and southern margins of the Mesozoic terrestrial siliciclastics of the Khorat Plateau (Burrett et al., 2014a; Khin et al., 2014) (Figure 1). The Loei-Phetchabun Terrane (Figure 1) is characterized (Table 1) by Devonian basaltic volcanism overlain by localized Givetian macrofossiliferous marine siliciclastics, Upper Givetian stromatoporoid-coral patch reefs overlain by Upper Devonian to Tournaisian shales and radiolarian cherts and, in turn, overlain by Tournaisian turbidites and early Visean terrestrial to marginal marine sediments including coals and evaporites (Chairangsee et al., 1990; Saesaengseerung et al., 2007; Udchachon et al., 2017) (Figures 2, 3). These sediments interdigitate with a "late" Carboniferous volcanic arc in the Phetchabun Province area (Salam et al., 2014) and all are overlain by widespread Visean to Permian platform carbonates (Ueno and Charoentitirat, 2011; Udchachon et al., 2015). Arc magmatism is again established in the Phetchabun Province area and along the southern margin of the Khorat Plateau in Thailand and Cambodia in the Permian to Late Triassic (Salam et al., 2014; Udchachon et al., 2018; Cheng et al., 2019) (Figures 1-5).

The Loei Foldbelt in NE Thailand may be divided into eastern (East Loei on Figure 1) and western belts separated by an easterly dipping thrust fault (Chairangsee et al., 1990). Close to this thrust, Charusiri et al. (2002) studied serpentinites and detrital chrome spinels which they suggested marked a terrane boundary which they named the Loei Suture (Figures 1, 2). We have recently found new outcrops of, as yet undated, serpentinised ultramafics with some showing original dunitic texture, further south along the suture (Figure 6). From DTEM analysis the thrust fault continues north, across the Mekong River, into Laos and extends south to curve eastwards under the Khorat Plateau (Figure 1). Its continuation under the Khorat Plateau is poorly constrained as few seismic profiles have been interpreted in detail below the "mid-Carboniferous" unconformity which is picked and obvious on many seismic sections (Figure 3; Booth and Sattayarak, 2011; Minezaki et al., 2019). The continuation of the Loei Suture under the Mesozoic siliciclastics of the Khorat Plateau succession (Figure 1) probably parallels the "... complexly foliated and thrusted [pre 'mid'Carboniferous] basement with a fabric striking NW-SE which dips at a moderate angle to the NE." (Booth and Sattayarak, 2011, p. 189) (Figure 1). We tentatively place the boundary between the Loei-Phetchabun and Truong Son terranes close to the major NW-SE thrust shown on the seismic top of the pre"mid"-Carboniferous basement map of Minezaki et al. (2019; their Figure 8) (Figure 1). We suggest that the Loei Suture joins the Tamky Suture (TKS on Figure 1). In the Loei Foldbelt of N.E. Thailand the stratigraphy on either side of the Loei Suture is different with, in the eastern part of the foldbelt, Silurian to Early Devonian mainly siliciclastics and volcaniclastics and minor limestones with a Silurian to early Devonian coralbrachiopod fauna, interdigitating westwards with a dated Silurian to Early Devonian volcanic arc east of the Loei Suture (Figure 5) (Fontaine et al., 2005; Khositanont et al., 2013; Zhao et al., 2016). The continuation of the eastern Loei belt northwards into Laos contains a similar succession except that older Ordovician limestone (with brachiopods) and igneous rocks are also present with dacitic tuff at $449.6+/-2.6$, rhyolitic tuff at $419.8+/-2.6$, and a dioritic dyke at $417+/-4.9 \mathrm{Ma}$ (Long et al., 2019). We therefore separate the eastern Loei Foldbelt in Thailand and Laos from the western Loei Foldbelt and place it within the Truong Son Terrane. We suggest that the Loei Thrust/Loei Suture of Charusiri et al. (2002) is the western boundary of the Truong Son Terrane (Figure 1).

\section{Truong Son Terrane}

The Truong Son Terrane (Figures 1, 2, 4, 7) contains sedimentary sequences dating from the late Cambrian (Furongian) through to the Cenozoic (Figures 4, 5, 7-12). The Palaeozoic successions have been well-studied in Vietnam but many publications are in Vietnamese and difficult to acquire. Older literature is mainly in Russian and French and is also 


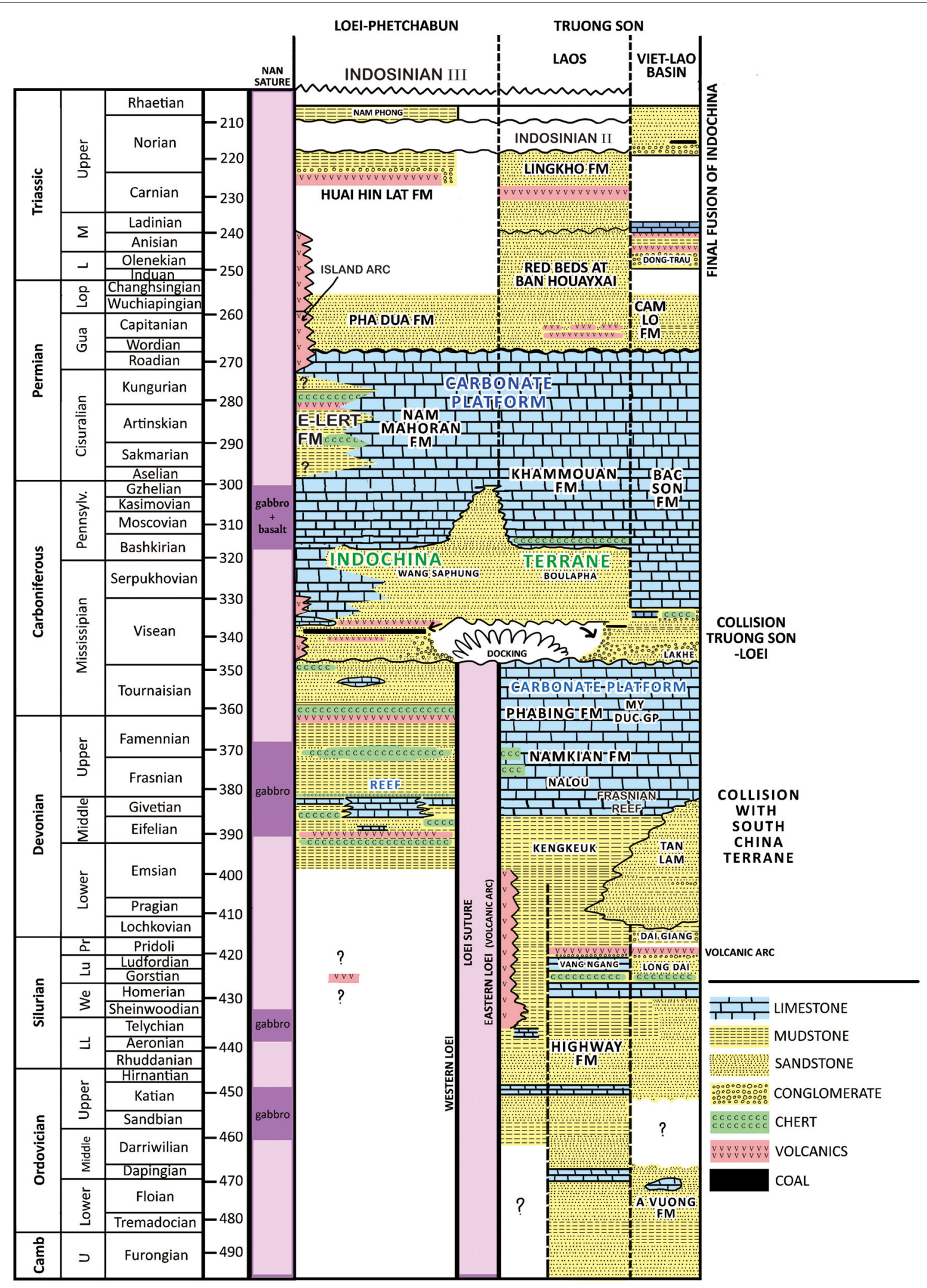

FIGURE 2 | Summary diagram of present hypothesis showing summaries of stratigraphies, deformation episodes, and magmatic events in the Loei-Phetchabun and Truong Son terranes. Stratigraphic data are from numerous sources. Ordovician gabbro within the Nan Suture is from Khin et al. (2014) and Long et al. (2019) and Devonian and Carboniferous dates are from Shen et al. (2010a). The Tan Lam Formation in the Vietnamese sector of Truong Son represents the influx of coarse terrigenous siliciclastics caused by the first collision of the Truong Son Terrane with the South China Terrane in the late Silurian to Early Devonian. 

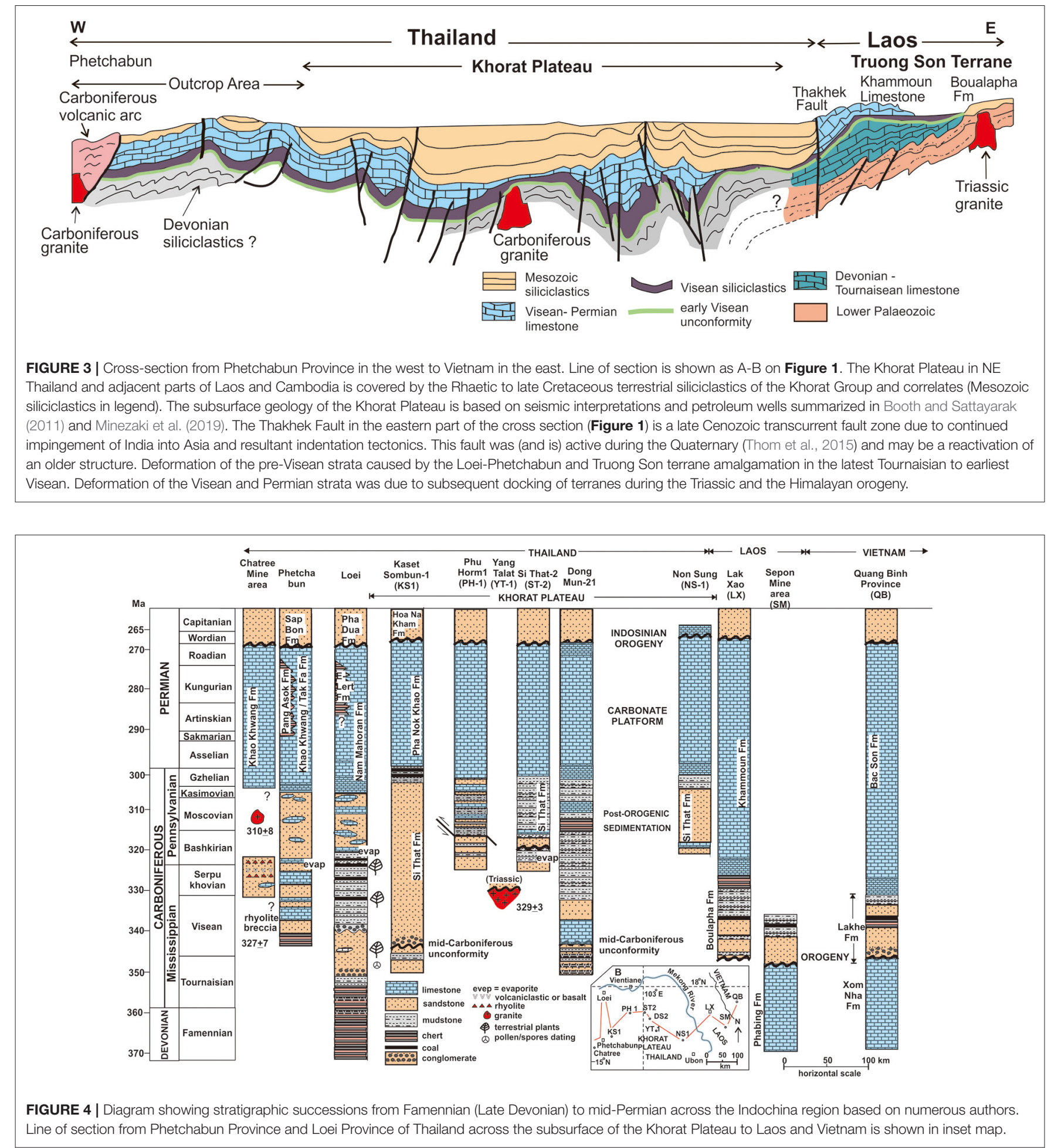

difficult to access. However, it is clear that the well-studied and dated sequences around the Sepon Mine in Lao PDR (Figures 7, 9-11) are similar to those further north in Laos (Ban, 2000; Ban et al., 2000a,b; Cannell et al., 2015; Udchachon et al., 2015; Thassanapak et al., 2018) and to those in the Vietnamese parts of the terrane (e.g., Thanh et al., 2007; Tri and Vu, 2011) and are summarized in Figures 2, 4-7. The Truong Son Terrane sedimentary succession consists of upper Cambrian to Upper Ordovician siliciclastics and minor carbonates, Silurian graptolitic shales, cherts and minor limestone, Early to 


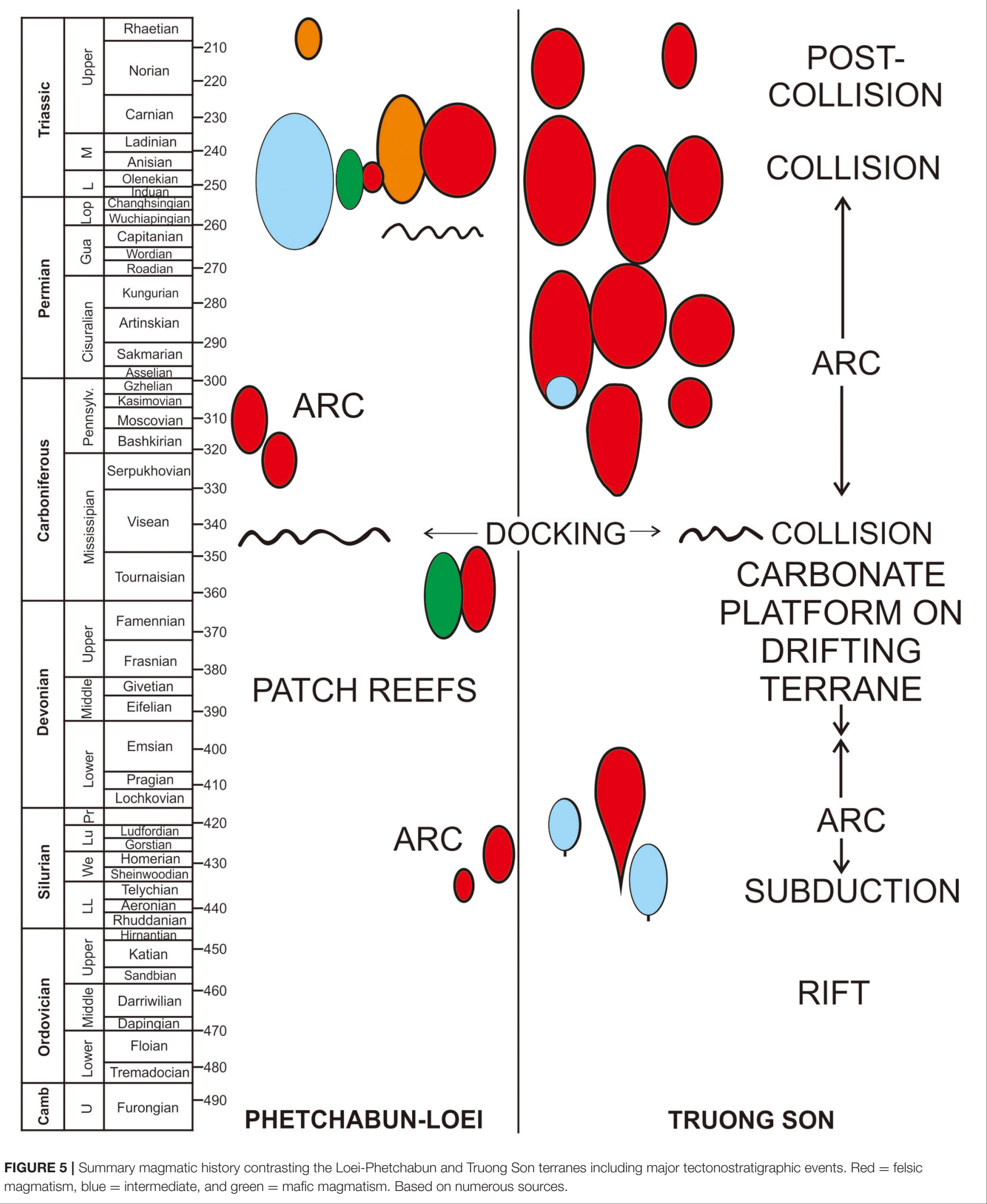




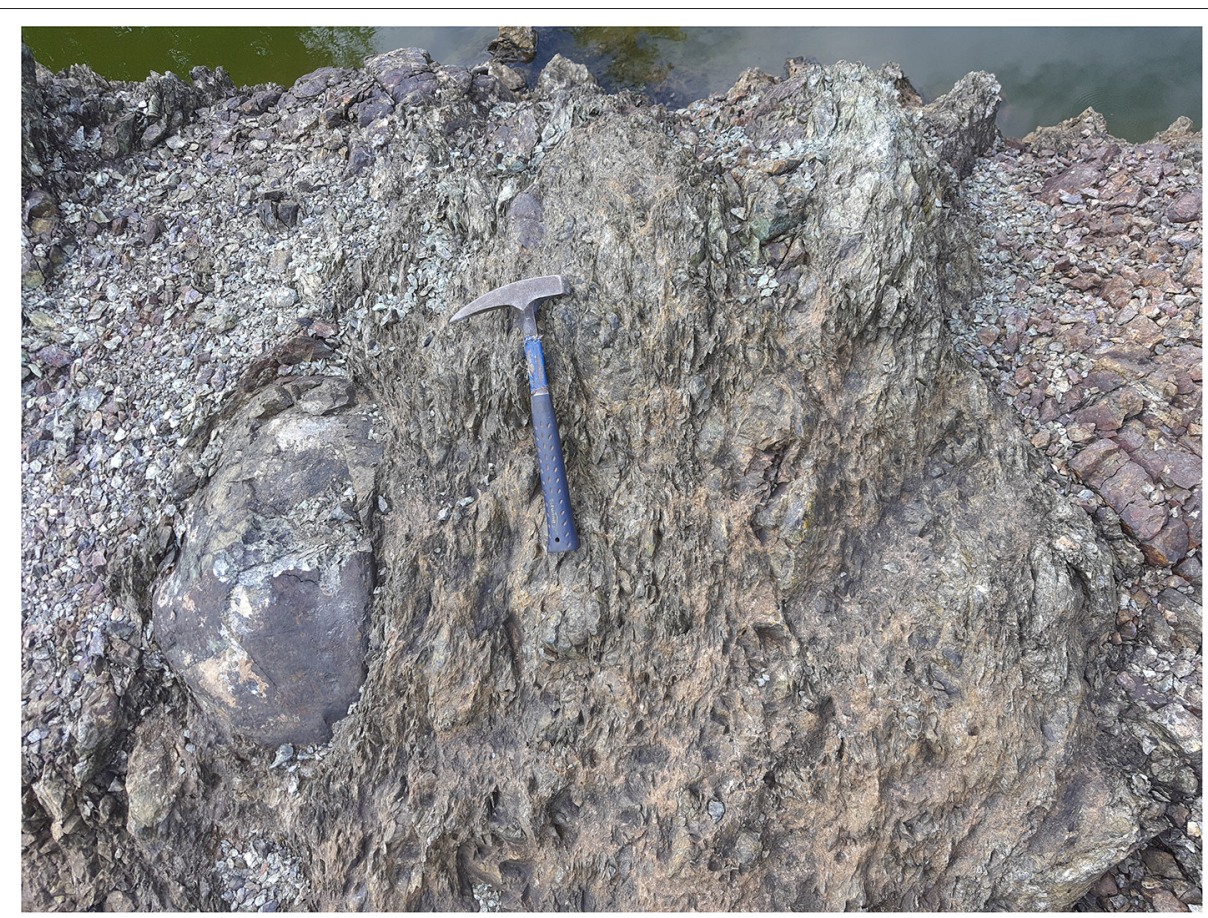

FIGURE 6 | Serpentinite outcrop from east of Pak Chom, Loei "Foldbelt," N.E. Thailand with some areas showing original dunite texture. This and other outcrops of serpentinite mark the Loei Fault/ Suture separating the Loei-Phetchabun Terrane in the west from the Truong Son Terrane in the east in the Loei "Foldbelt".

Middle Devonian siliciclastics, Frasnian marginal platform reef complexes, an extensive carbonate platform from the Frasnian to the Tournaisian, coarse to fine siliciclastics from the Tournaisian to the Visean, and a final platform carbonate succession diachronously established from the Visean through to the midPermian (Figures 8-12). This later carbonate platform extends across both the Truong Son and Loei-Phetchabun terranes where it includes many intra-platform basins containing deep-water shales and cherts (e.g., Booth and Sattayarak, 2011; Ueno and Charoentitirat, 2011; Burrett et al., 2014b; Minezaki et al., 2019) (Figure 3). Both in the subsurface and in outcrops, this very extensive carbonate platform is terminated by a diachronous siliciclastic influx mainly in the mid-Permian (Figures 2, 4). However, in parts of Phetchabun Province carbonate deposition extends to the Wuchiapingian (late Permian) (Hada et al., 2020).

Older studies on igneous assemblages in the Truong Son Terrane relied on easily re-set $\mathrm{K}$-Ar dates but recent work has included more reliable dates using zircons, ${ }^{40} \mathrm{Ar}^{-\mathrm{Ar}^{39}}$ and monazites along with detailed trace element and isotope data. The papers by Sanematsu et al. (2011), Liu et al. (2012), Kamvong et al. (2014), Manaka et al. (2014), Nakano et al. (2013), Shi et al. (2015), Wang et al. (2018), and Wang et al. (2020) are particularly important (Figures 5, 7). These authors find that the granitoids of the Truong Son Terrane are either mainly Ordovician-Silurian or latest Carboniferous to Triassic in age with restricted magmatism in-between (Figures 5, 7). Shi et al. (2015) suggest that there were at least four stages of magmatic activity, a-d, below. All granites and rhyolites studied by Shi et al. (2015) are Volcanic Arc (VAG) rocks. The Silurian biotite granite of the Hai Van Complex (NW of Danang) plots as calc-alkaline and S-type. Permo-Triassic granitoids plot as either S or I-type. Stage a of Shi et al. (2015) has extensive VAG granites ranging from 470 to $420 \mathrm{Ma}$ (Middle Ordovician to latest Silurian). Stage $\mathrm{b}$ includes latest Carboniferous to early Permian VAG associated with $\mathrm{Cu}-\mathrm{Au}-\mathrm{Fe}$ mineralisation with north dipping subduction along the Tamky Suture and under the Truong Son Terrane. Stage c has 270-245 Ma (mid-Permian to mid-Triassic) arc-magmatic hydrothermal $\mathrm{Cu}-\mathrm{Au}-\mathrm{Fe}$ and orogenic W-Sn- Au deposits linked to both southwards subduction from Song Ma and the closure of Tamky-Phuoc Son ocean. Ilmenite series granitoids are the same age as the well-known tin granites of SE Asia and include the central Laos granites near Boneng and Phontiou (247 Ma) and the Nape Complex (244, 235, 221, 208, and $199 \mathrm{Ma}$ ) (Sanematsu et al., 2011). Stage d consists of 245-200 Ma syn- and post collisional magmatism with epithermal Fe-Au-W-Sn deposits.

The Truong Son Silurian granitoids overlap in age with the andesitic flows, porphyritic diorite, and the volcaniclastic submarine fan of the Namphuc Formation at the Sepon Mine (439-433 Ma, Thassanapak et al., 2018) and the volcanics of the Long Dai Formation in Vietnam. These mainly andesitic volcanics are termed the Long Dai Volcanic Arc in the Vietnamese literature (De, 1997; Tri and Vu, 2011). Wang et al. (2020) have recently studied the geochemistry of intermediate to basaltic volcanics and gabbros from the southern Truong Son Terrane and obtained early to middle Silurian zircon dates. Their trace element compositions plot as a volcanic arc with some incorporation of sediments. The existence of a southern Truong Song Terrane island arc with northerly subduction under 


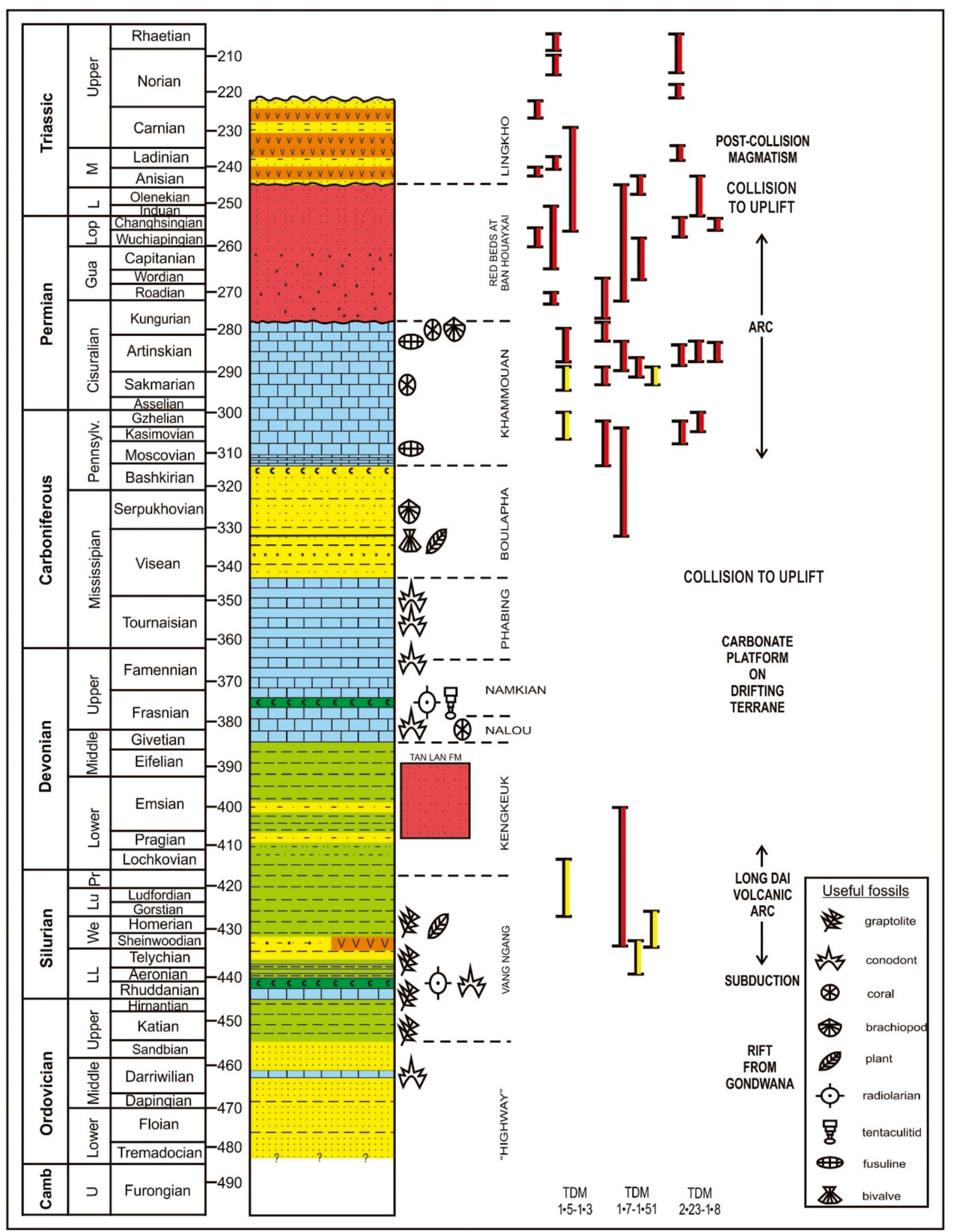

FIGURE 7 | Stratigraphic and plutonic igneous summary of the Truong Son Terrane based mainly on successions at well-dated formations at the Sepon Mine. The Tan Lam Formation in the Vietnamese sector of Truong Son represents the influx of coarse terrigenous siliciclastics caused by the first collision of the Truong Son and South China along the Song Ma Suture in the late Silurian to Early Devonian. Red lines are age ranges of felsic igneous rocks including granites and rhyolites. Yellow are andesites and diorites. Compiled from numerous sources. 

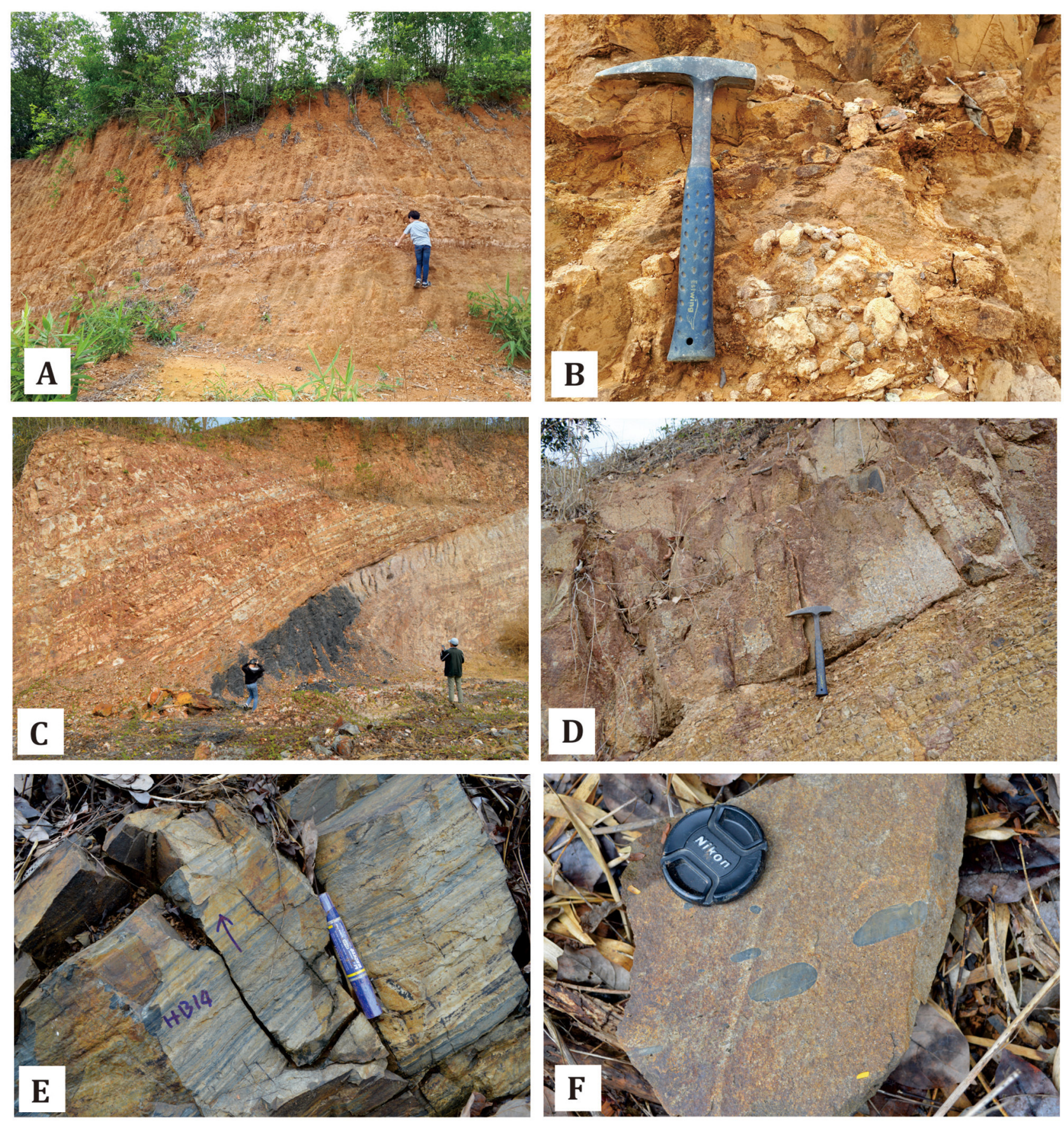

FIGURE 8 | Field photographs of significant Palaeozoic sequences in the Loei "Foldbelt" NE Thailand (LOEI on Figure 1). (A,B) are Silurian to Early Devonian volcaniclastics from east of the Loei Suture in the eastern part of the "Loei Foldbelt" belonging to the Truong Son Terrane as interpreted herein. This sequence is associated with marly mudstone and thin limestones with prolific corals and stromatoporoids. (C-F) are early Carboniferous siliciclastics in the Loei Foldbelt resulting from the proposed collision of the Truong Son and Loei-Phetchabun terranes. (A,B) Late Silurian to Early Devonian siliciclastic sequence from Ban Na Gniew in the east of Pak Chom in the Truong Son Terrane east of the Loei Suture (Loei Fault). This siliciclastic-volcaniclastic succession contains lighter colored limestone hardgrounds with a coral (e.g., Heliolites, Favosites), brachiopod, and trilobite fauna which interdigitate with a late Silurian to Early Devonian volcanic arc toward the west. (B) Close-up of A showing large domal tabulate coral. Brachiopods, trilobites, and other benthic faunas are common in this succession. (C) Carboniferous siliciclastic sequence with anthracitic coal from west of Pak Chom of possible late Visean age as a consequence of collision and uplift. (D) Channel conglomerate overlying thin-bedded shale and sandstone (greywacke) of proximal to distal submarine fan lobe. This sequence indicates the beginning of early Carboniferous (late Tournaisian to early Visean) collision in the region. (E) Siliceous shale showing lamination with flame structure indicative of a turbiditic event deposited between a distal fan lobe and basin and the result of the postulated Tournaisian - early Visean terrane collision. (F) Conglomerate showing rounded pebble clasts in the channel truncating the submarine fan. This unit is observed in association with a fine turbidite succession of late Tournaisian to early Visean age. 

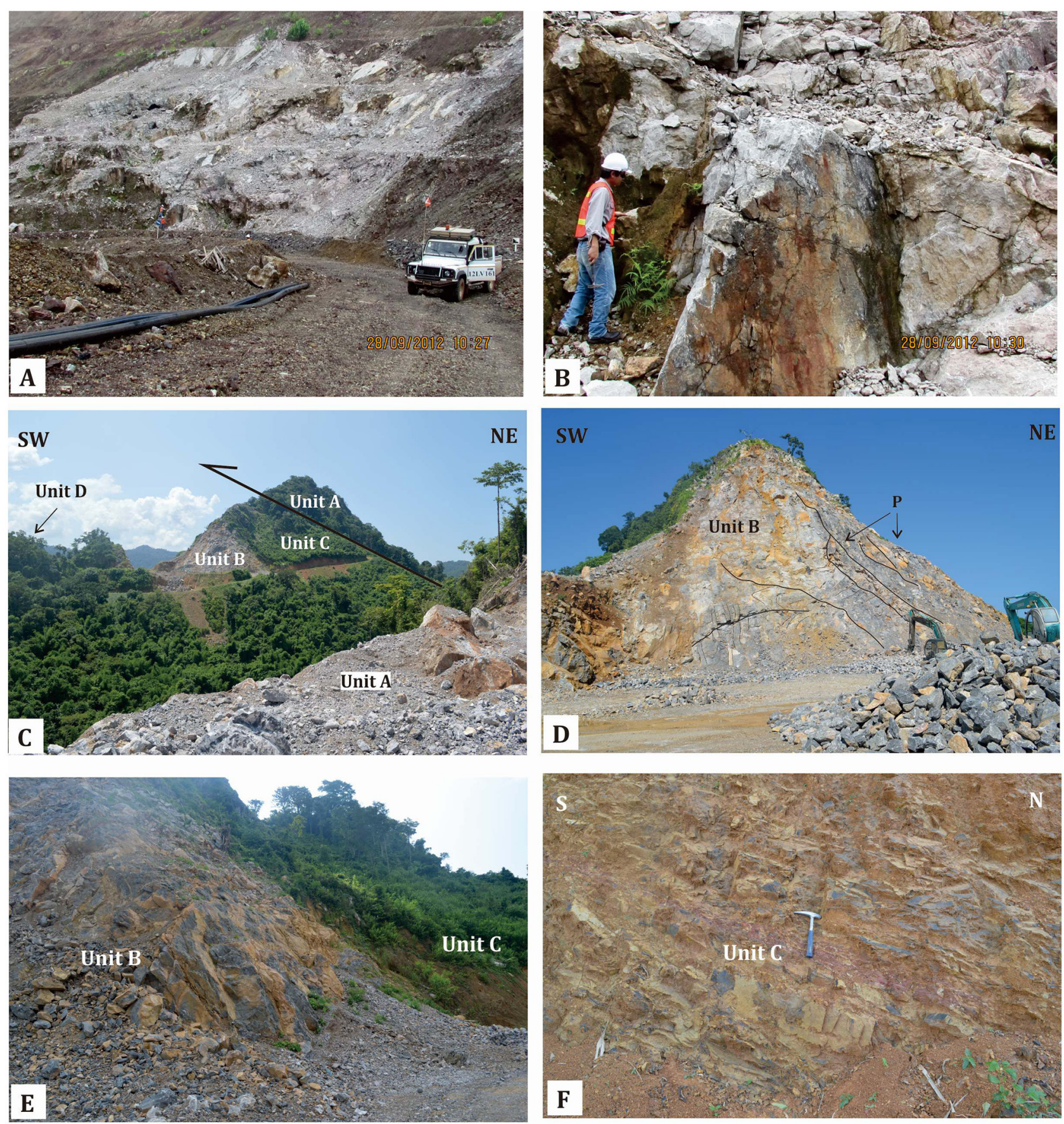

FIGURE 9 | Deformed and stratigraphically out-of-sequence light colored Wenlockian age limestone associated with black early Silurian graptolitic shales, and late Silurian radiolarian cherts of the Vang Ngang Formation at Sepon Mine, Laos. Southern margin of Truong Son Terrane. This is possibly an accretionary prism. (A) Sharp contact of Wenlockian limestone unit with Llandoverian shale and Ludlovian chert sequence. (B) Close-up of Wenlockian limestone showing strongly sheared block of the limestone [see Loydell et al. (2019) and Thassanapak et al. (2018) for details].Truong Son Terrane, Laos. Field photographs of limestone quarry $20 \mathrm{~km}$ south of the Sepon mine but north of Tamky-Phuoc Son Suture (Figure 1 for location), near southern margin of Truong Son Terrane showing Middle to Late Devonian and lower Carboniferous carbonate and younger siliciclastic succession. (C) Showing thrust slice of Middle to Upper Devonian carbonate succession (Unit A, as seen in foreground) over lower Carboniferous carbonate-siliciclastics (Units B, C, and D). (D) Main quarry showing complex structure including thrust fault with phacoid $(P)$ and recumbent fold with vergence to the south. (E) Gradational contact between Unit B and Unit C showing evidence of upwards shallowing. (F) Unit C, siliciclastics - mainly light brown and red shale, interbedded with thin bedded siltstone and sandstone of a probable deltaic environment. 

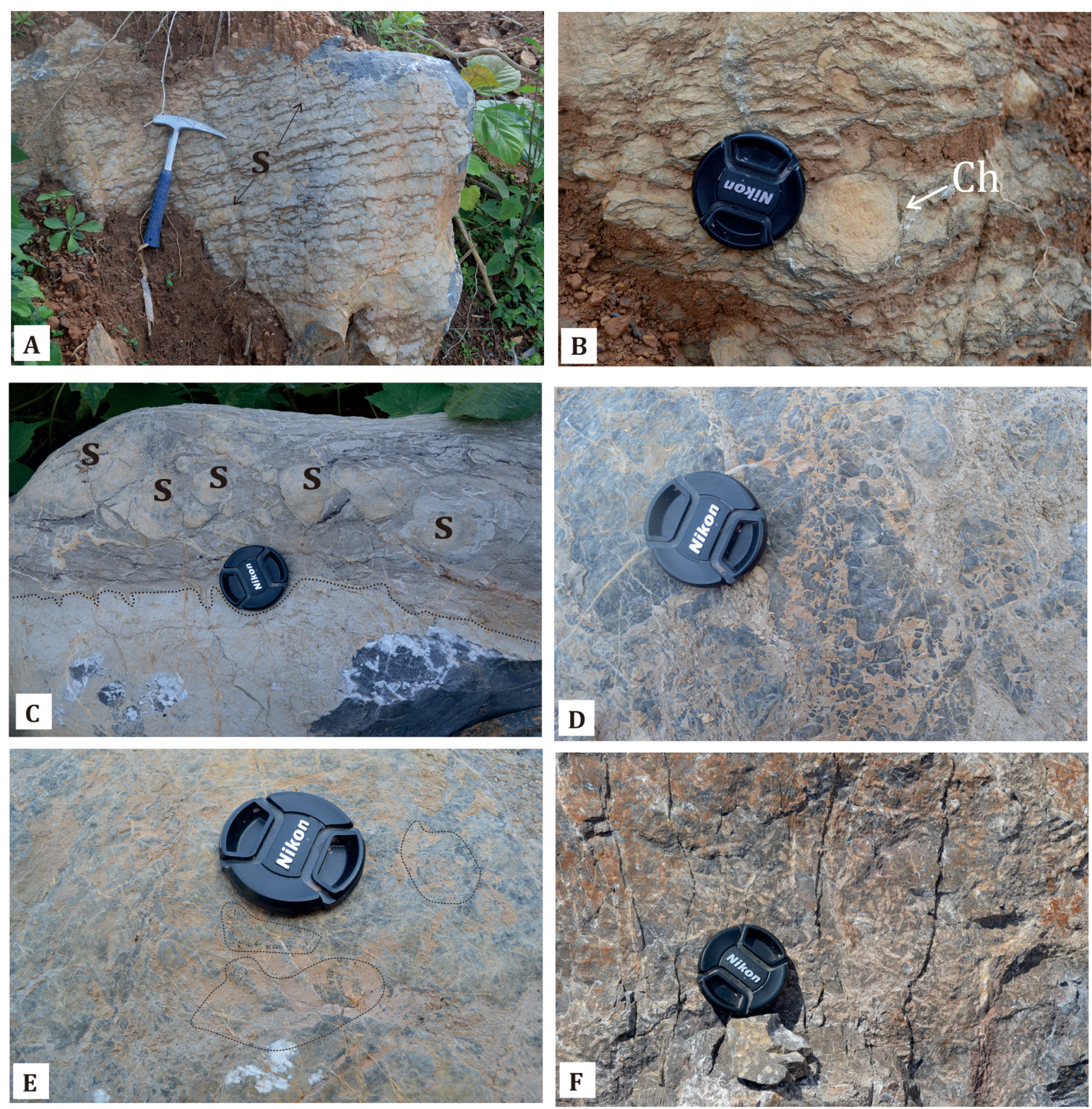

FIGURE 10 | Facies variation of limestone from Unit A of Figure 9. (A) Stromatolitic limestone (algal laminite) with small domal stromatoporoid. (B) Stromatolitic limestone with Chaetetes (Ch) (sponge) in growth position. (C) Micritic limestone with truncation on top and overlain by limestone breccia (intraformational breccia). The sharp truncation suggests aerial exposure and karstification. Clasts of limestone breccia consist of large domal fragments of stromatoporoid (S), skeletal debris, and lithoclasts. (D,E) limestone breccia with abundant clasts of tabulate corals (?Thamnopora). This evidence suggests the existence of a stromatoporoid-coral reef prior to the collapse of the carbonate platform. (F) Reef limestone (foreground of Figure $\mathbf{9 C}$ ) showing abundant Stachyodes (stromatoporoid).

the Truong Son Terrane during the Late Ordovician to "mid" Silurian is therefore well-established. However, Wang et al. (2020) also recently briefly studied dated and analyzed similar aged volcanics from west of the Poko Fault and north of Attapeu in southern Laos (Figure 1). The terrane affinities of this area are presently unknown but it may be a westerly extension of the Tamky Suture. On the basis of these volcanics, Wang et al. (2020) only suggest southerly subduction under the Kontum Terrane and do not provide an explanation for the arc volcanics in southern Truong Son.

Speculatively, the deformed and stratigraphically out-ofsequence graptolitic shales, limestone, and radiolarian cherts 

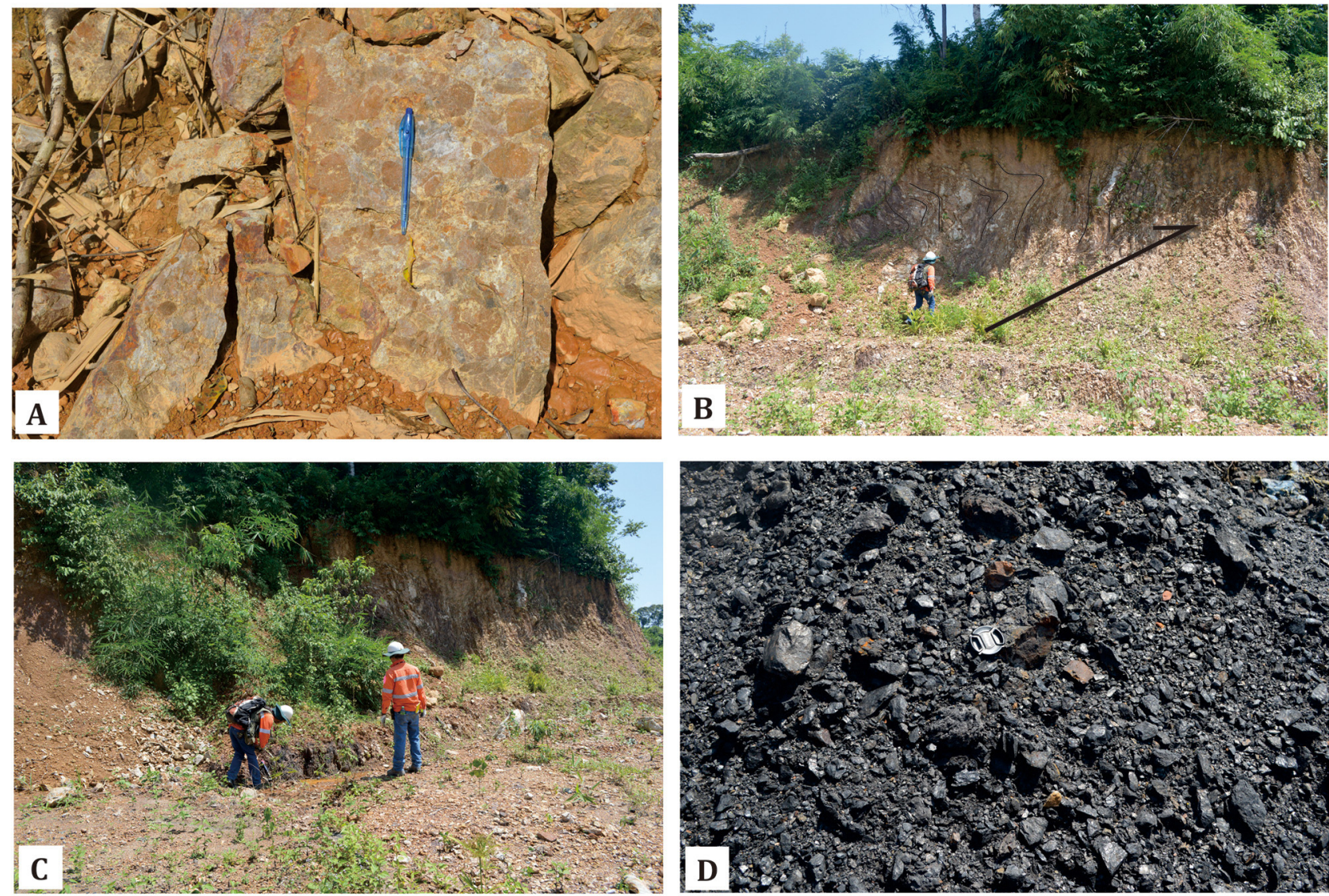

FIGURE 11 | Field photograph of Unit D of probable Boualapha Formation correlate $20 \mathrm{~km}$ south of the Sepon Mine but north of Tamky Suture (see Figure 1 for location). This unit consists mainly of a folded siliciclastic sequence, but the main competent units dip at $40^{\circ} \mathrm{N}$. The lithofacies of this unit suggests a fluvial environment which overlies Unit C. Unit D consists of siltstones, quartz arenites, pebbly arkosic sandstone, quartzites, and conglomerates. (A) Conglomerates, (B) Folded fine siliciclastics with coal seam and plant remains. Vergence of the fold is to the south, (C) Unit D with coal seam, (D) Close-up of anthracitic coal.

of the Vang Ngang Formation in the Sepon Mine area are typical of accretionary prisms and may constitute a fore arc assemblage (Thassanapak et al., 2018) (Figures 9A,B). The deepwater Silurian succession of southern Truong Son grades north into shallower marine siliciclastics (Thassanapak et al., 2018). By the late Silurian, coarse siliciclastics in the central Vietnamese part of Truong Son containing South China-type fish may indicate the first contact between Truong Son and the Song Da Terrane of the composite South China Terrane in North Vietnam (Janvier et al., 1997; Thassanapak et al., 2018).

\section{Kontum Terrane}

The Kontum Terrane (previously Kontum "Massif”) contains the oldest rocks in Southeast Asia and was, until modern dating, thought to be an Archean core around which the Proterozoic to Phanerozoic rocks accreted (e.g., Fromaget, 1927, 1941). From numerous studies dating the igneous and metamorphic rocks of the Kontum core complex it is clear that the volume of Archean rocks is negligible and that Proterozoic to Palaeozoic plus Triassic intrusives are dominant, with the oldest metamorphic protoliths being Mesoproterozoic at $1,450 \mathrm{Ma}$ (Nakano et al., 2020)
(Figure 13). The presence of charnockites, previously thought to be typically Precambrian and are now dated as Permian, are amongst the youngest dated charnockites worldwide but are nevertheless characteristic of the Kontum Terrane (Table 1; Lan et al., 2003; Maluski et al., 2005). Phanerozoic intrusives range from mid-Ordovician to Early Devonian (Figure 13) and from late Permian (Lopingian) to Late Triassic (Norian) with a peak at the middle-late Triassic boundary (Figure 13). There is very little magmatism dated as Late Devonian to early Permian (Hieu et al., 2015). The western boundary of the Kontum Terrane is usually taken as the north-south trending Poko Fault (Figures 1, 13). Serpentinites within the fault zone suggested a Poko Suture and westward subduction to Lepvrier et al. (1997, 2004, 2008) separating the Attapeu region (AT on Figure 1) and a small part of Vietnam, from the Kontum Terrane to the east (Figure 13). These serpentinites and apodunites are strongly altered to "metahyperbasite and metapyroxenite" but their age is inferred by correlation to ultramafics in the Tamky Suture dated as $477 \mathrm{Ma}$ (Early Ordovician) (Izokh et al., 2006; Tri and Vu, 2011, p. 229-231, Figure III 4.3). A late Permian granite cuts the Poko Fault and constrains the fusion age 

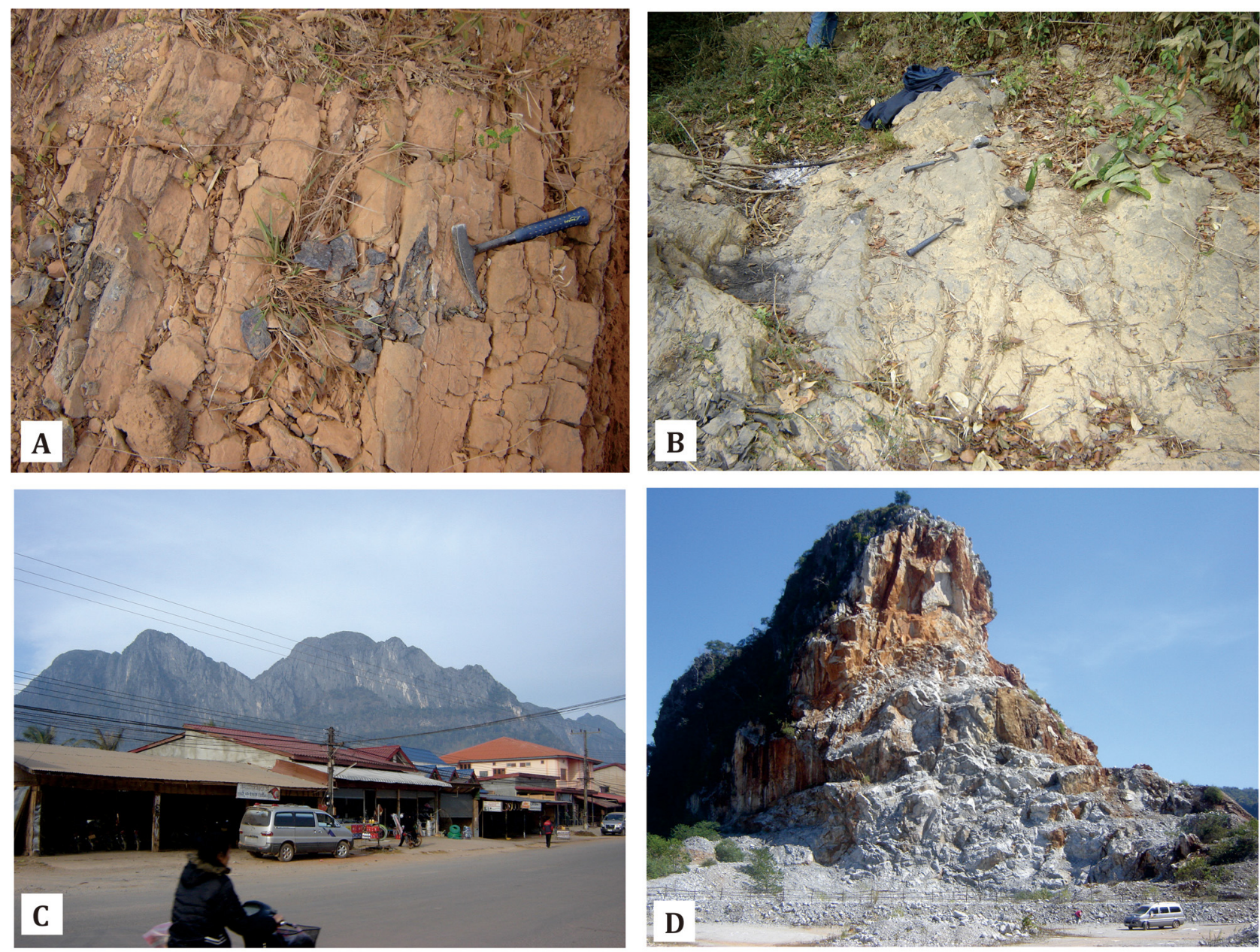

FIGURE 12 | Field photographs of Boualapha Formation and Khammouan Group from central Laos. (A) Outcrop of carbonaceous limestone belonging to the Boualapha Formation north of Boualapha Town. (B) Close-up of (A), (C) Large outcrop of limestone of the Khammouan Group north of Lak Xao Town. (D) Limestone belonging to the Khammouan Group, south of Lak Xao Town, central Laos [see Figure $\mathbf{4}$ and Thassanapak et al. (2012) for localities]. Lak Xao township is shown as LX in Figure 4.

of Kontum with regions to the west (Figure 13; Tran et al., 2014). In regions immediately west of the Poko Fault, in Attapeu, Devonian and Carboniferous intrusives have been dated (Vilayhack, 2010; Sanematsu et al., 2011). However, magmatic zircons from part of the Antoum Pluton are dated as 470 $+/-2 \mathrm{Ma}$ and a proximal rhyolitic tuff as $476+/-1.5 \mathrm{Ma}$ and their arc geochemistry indicates Early Ordovician subduction (Gardner et al., 2017). The presence of Early Ordovician magmatism in Attapeu suggests affinities to the Truong Son Terrane rather than the Loei-Phetchabun Terrane (Gardner et al., 2017; Wang et al., 2020) and outcrops of supposed Ordovician limestone (Vilayhack, 2010) could support this interpretation. However, logistic problems of working in this area and a paucity of information make a definite terrane attribution of the Attapeu region impossible. Just to the west of the Poko Fault unmetamorphosed fossiliferous Early Devonian sediments of the $\mathrm{Cu}$ Brei Formation (Figure 13) rest unconformably on granites dated by K/Ar as $418+/-12$ Ma to $384+/-17$ Ma showing that this region was not strongly affected by the extensive Triassic (Anisian to Carnian) metamorphism of the Kontum Terrane (Osanai et al., 2004; Nakano et al., 2007, 2009, 2013, 2020; Thanh et al., 2007).

\section{TERRANE PROVENANCE}

There is very little high quality palaeomagnetic data available that constrains the palaeogeographic positions of the Indochina terranes in the Palaeozoic. Yan et al. (2018) found a southerly palaeolatitude of $21^{0}+/-6^{0}$ for Permian limestones from the Loei-Phetchabun Terrane. A "mid-Carboniferous" pole from western Yunnan gave a similar southern palaeolatitude of $18.4^{0}+/-4^{0}$ but that site's terrane affinity is uncertain (Yan et al., 2020). Burrett et al. (2014a) proposed that zircon age probability plots obtained from formations at the Sepon Mine area on the Truong Son Terrane suggested the Himalayan sector of Gondwana as the source region. Uzuki et al. (2013) 


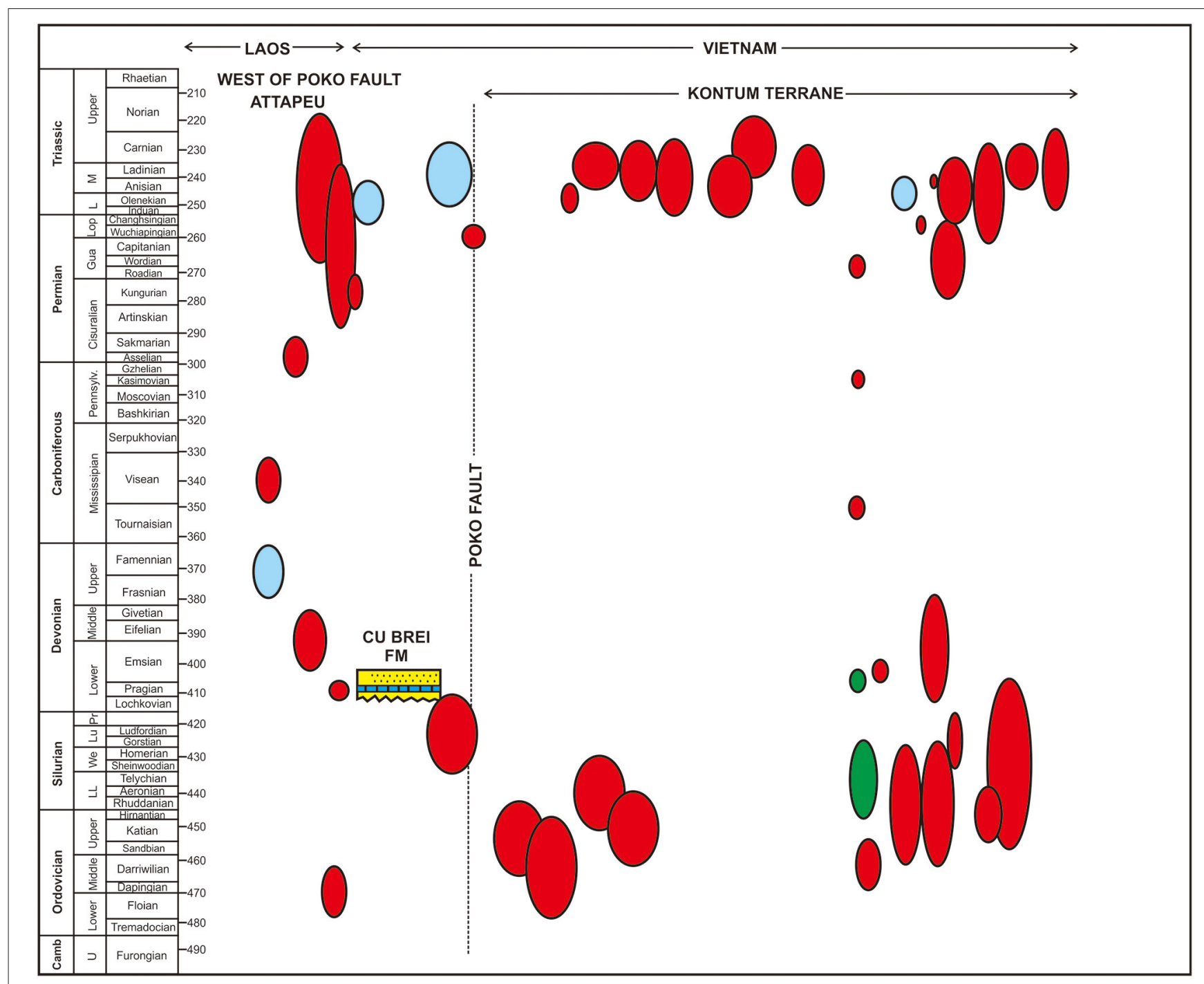

FIGURE 13 | Summary of plutonic magmatism in the Attapeu region of Laos (AT on Figure 1) and adjacent areas in Vietnam, west of the Poko Fault (POK on Figure 1) and the Kontum Terrane east of the Poko Fault. Note the significant difference in magmatic history and stratigraphy on either side of the Poko Fault. Note that the Early Devonian Cu Brei Formation is west of the Poko Fault and, unlike the Kontum Terrane, is unmetamorphosed. Palaeozoic strata do not outcrop on the Kontum Terrane. Light blue $=$ intermediate - mafic intrusives, red = felsic/acidic intrusives, and green $=$ amphibolites - mid-plate tholeiites.

working on zircons obtained from modern river sediments in the north of Truong Son, independently came to the same conclusion.

There are very few fossils that help in locating the Indochina terranes. Graptolites from the Llandoverian shales of the Sepon Mine near the southern boundary of the Truong Son Terrane are characteristic endemic species of southern Europe and the Middle East rather than South China (Loydell et al., 2019). Graptolites were planktonic but this distinctive southern European fauna did not float to either northern Europe or South China. This suggests a placement of Truong Son attached to the Middle East-southern European sector of peri-Gondwana or in an oceanic area where these distinctive graptolites might have drifted. Given their limited biogeographic distribution they provide evidence that Truong Son was not attached or even close to South China in the Llandovery (Loydell et al., 2019). Ordovician conodonts from limestone within the mainly siliciclastic "Highway" Formation of the Sepon Mine area are of a North Atlantic type which suggests either deep and cool or shallow non-tropical seas (e.g., Burrett et al., 1984). As these limestone lenses are shallow marine, based on their dolomitized cyanobacterial mats, it is most likely they were deposited in temperate and not tropical palaeolatitudes and on the basis of their zircons were deposited in the Himalayan/Middle East sector of peri-Gondwana (Burrett et al., 2014b; Thassanapak et al., 2018). 


\section{RIFTING FROM GONDWANA}

The Truong Son Terrane in Laos and Vietnam and in east of the Loei Foldbelt in Thailand is characterized by siliciclastics ranging from the Early to Late Ordovician (Figures 2, 7; Thassanapak et al., 2012). They are succeeded in the Silurian of Laos and Vietnam by deep-water radiolarian cherts and volcanics of the Vang Nang Formation (at Sepon) and the Long Dai Formation and Long Dai Volcanic Arc in Vietnam. Dacitic tuffs of arc affinity are dated as latest Ordovician in the Truong Son Terrane's eastern Loei foldbelt (Long et al., 2019). This suggests Truong Son's attachment to a continental margin in the Ordovician and rifting in the Late Ordovician allowing both very deep marine conditions in the Silurian and the establishment of a subducting and arc-producing margin by the Llandoverian. It is now well-established that a subducting margin occurred along the "Tethyan" margin of Gondwana from Sibumasu through to the Himalayas, the Tibetan terranes and further to southern Europe during the late Cambrian to Ordovician (e.g., Lin et al., 2013).

The Early Palaeozoic Kontum Terrane granitic gneisses range from $462 \mathrm{Ma}$ (Darriwilian) through to $422 \mathrm{Ma}$ (Ludlow) (Nakano et al., 2007, 2013, 2020) and may have formed during this Gondwana-margin subduction prior to rifting in the latest Ordovician to Silurian. Granitoids dated within the Tamky Suture as "middle" Cambrian (518+/-7 Ma and 502+/- 6 Ma) are typical oceanic plagiogranites and were probably formed in a volcanic arc in this ocean subducting toward the south (present day) under Gondwana (Nguyen et al., 2019).

As the Kontum Terrane detrital zircon spectra contain Grenvillian orogeny age peaks (1,200-1,000 Ma), Nguyen et al. (2019) suggest placement of the Kontum Terrane close to western Australia (Zhu et al., 2011; Burrett et al., 2014a). Thus, the meager evidence currently available suggests that the Truong Son Terrane was located as part of the Himalayan or even Middle Eastern part of Gondwana and rifted off in the latest Ordovician. The Kontum Terrane was closer to the west Australian part of peri-Gondwana and also rifted off Gondwana in the Late Ordovician or early Silurian. There is no evidence for the rifting time of the Loei-Phetchabun Terrane other than it was midDevonian or earlier.

\section{TERRANE AMALGAMATION}

Several suture zones in mainland SE Asia contain complex and controversial geological histories and record the amalgamation of the three Indochina terranes. The Song Ma Suture (Figure 1) forms the northern boundary of Truong Son. It appears to have been the site of collision between the composite South China Terrane (which includes Northeast Vietnam) twice (Tri et al., 2020). Closure and impingement of the Truong Son and South China terranes took place in the late Silurian with the influx of detrital siliciclastics into central Truong Son which include fish and invertebrate faunas with weak South Chinese affinities. However, by the Early Devonian the fish fauna is undoubtedly South Chinese (Thanh et al., 1996, 1997, 2011; Janvier et al., 1997; Janvier and Thanh, 1998; Young and Janvier, 1999; Young and
$\mathrm{Lu}, 2020)$ with affinities both to South China and to the wellknown fish fauna of the sandstones of the Do Son Formation of Haiphong, in northern Vietnam. The complex geology of the Song Ma Suture suggests that a simple single collision model is impossible. Some important and probably indisputable facts concerning the Song Ma Suture are:

1. Serpentinised ultramafics occur as large lenticular bodies along the Song Ma belt associated with metavolcanics and metasediments (Tri and Vu, 2011).

2. Dates on the ultramafics and associated gabbro and diorite range from $415 \mathrm{Ma}$ (U-Pb zircon), $414 \mathrm{Ma}(\mathrm{Sm}-\mathrm{Nd}), 414$ (Sm-Nd), and $387+/-6 \mathrm{Ma}$ (Sm-Nd and U-Pb zircon) (Tri and Vu, 2011). These are Early Devonian dates. Early Carboniferous mafic crystallization dates are also present in the Song Ma-Ailaoshan ranging from $362+/-8 \mathrm{Ma}, 347+/-$ $7 \mathrm{Ma}, 343+/-3 \mathrm{Ma}$, to $338+/-24 \mathrm{Ma}$ (Zi et al., 2012). These dates suggest ocean lithosphere formation at least from the Early Devonian into the early Carboniferous.

3. Monazite inclusions in garnet from phengite schists are $424+/-15 \mathrm{Ma}$ and may suggest subduction metamorphism (or at least a thermal event) in the Late Silurian (Nakano et al., 2010).

4. The Song Ma ophiolitic complex was unconformably overlain by rift basalts of the early to mid-Permian $(283+/-21 \mathrm{Ma})$ Cam Thuy Formation and intruded by subduction related Chieng Khoung and Dien Bien granites at about $271 \mathrm{Ma}$ (mid-Permian), (Liu et al., 2012).

5. The Hongvan serpentinite and gabbro is a remnant of oceanic lithosphere (Trung et al., 2006). The dismembered ophiolite was probably emplaced in a fore-arc setting formed by southerly (present day direction) subduction (Findlay and Trinh, 1997; Thanh et al., 2011, 2014).

6. Eclogite, indicating deep "subduction of sub-ophiolite oceanic basalt" to $>70 \mathrm{~km}$, was formed at $243+/-4 \mathrm{Ma}$ (monazite dating) and $230.5+/-8 \mathrm{Ma}$ (metamorphic zircon dating) during the Middle Triassic or Late Triassic (Nakano et al., 2010; Zhang et al., 2013) probably at the same time as granulite metamorphism about $25 \mathrm{~km}$ further south (Nakano et al., 2008).

7. The main regional metamorphic event in the Song Ma schists based on Ar/Ar dating was at 255-245 Ma (latest Permian to Early Triassic) (Lepvrier et al., 1997) and is the date of Findlay's (1997) S2 event.

Thus, subduction along the Song Ma Suture probably continued after re-opening of the Song Ma Ocean possibly in the Devonian as suggested by Tri et al. (2020) with subduction magmatism from 290 to $260 \mathrm{Ma}$ (Permian) and syn- to post-collisional magmatism from 245 to $230 \mathrm{Ma}$ (Anisian to Carnian) (Hieu et al., 2017) with final suturing in the Late Triassic but preceded by deep subduction of oceanic basalt to form eclogite in the Middle Triassic (Nakano et al., 2008, 2010). The Ailaoshan Belt in eastern Yunnan (Figure 1) is the northwest continuation of the Song Ma Suture and helps clarify the timing of the Truong Son - South China collision(s). Ailaoshan records "late" Carboniferous to early Triassic subduction magmatism, a late Permian arc-continent collision with convergent magmatism 


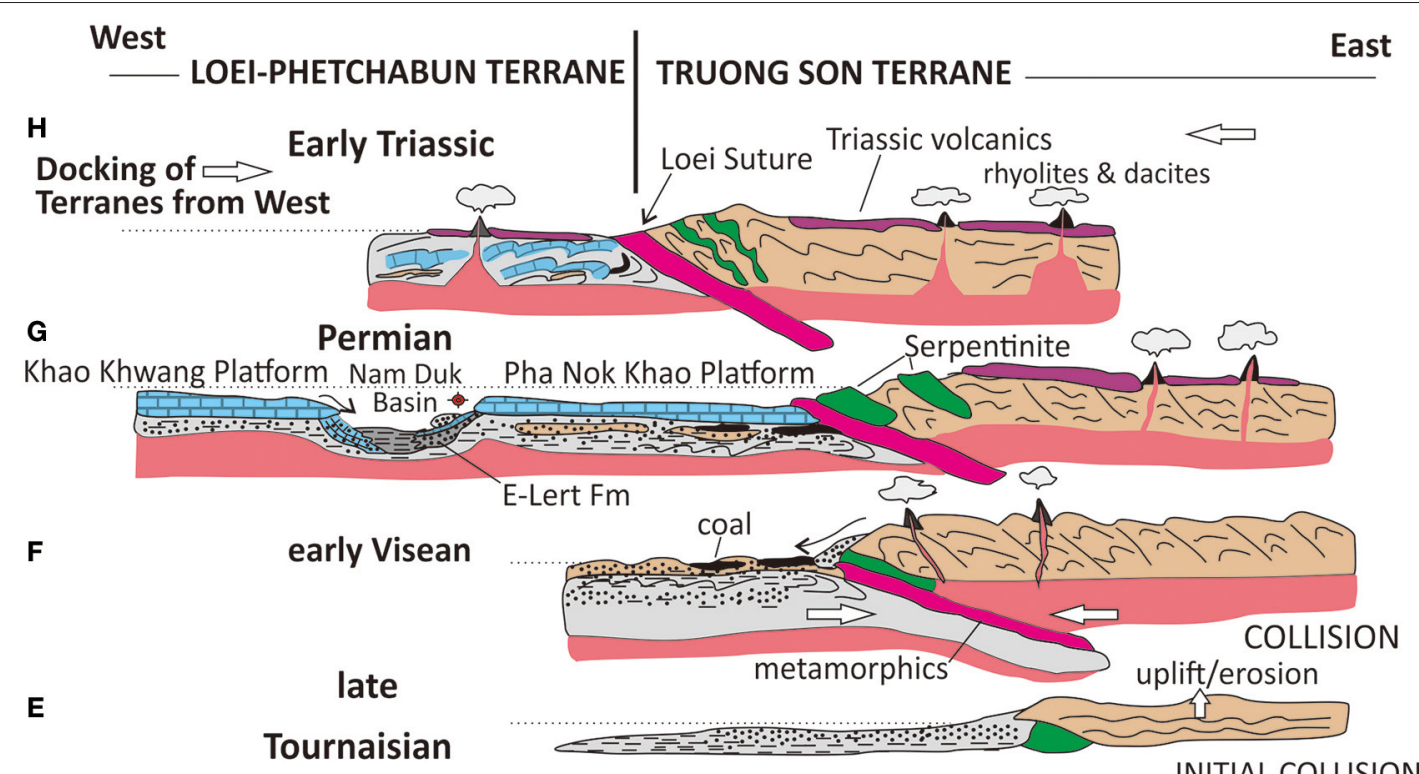

LOEI- PHETCHABUN TERRANE

INITIAL COLLISION

D Famennian to
early Tournaisian

C

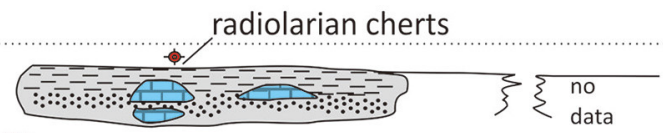
radiolarian cherts

\author{
(Givetian)
}
Middle Devonian

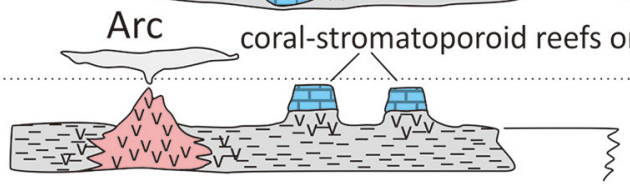

\}$\xi$

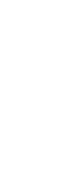

B

A

\section{subduction from Nan Suture}

\section{Silurian-} Early Devonian

\section{Ordovician}
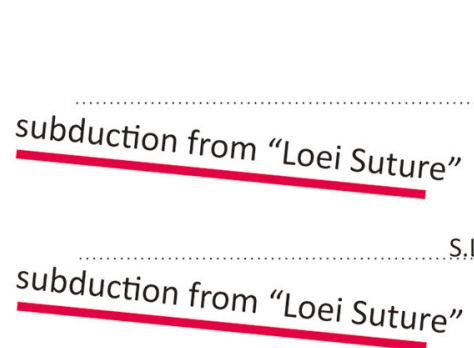

\section{TRUONG SON} TERRANE thin bedded limestone Arc with corals

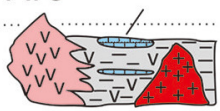

Arc

S.L.

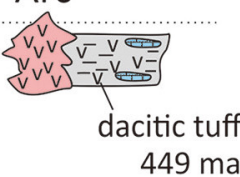

FIGURE 14 | Diagrammatic reconstructions, not to scale, showing the development of the Loei-Phetchabun and Truong Son terranes in northeast Thailand in Loei, Nong Khai, and Udon Thani provinces (south of Mekong River) and in an immediately adjacent part of Laos along and just north of the Mekong River. Line of section is shown in Figure 1. Fold vergence based on Chairangsee et al. (1990). Cardinal directions are present-day. In this area, the orogenic belt known as the Loei Foldbelt (Loei in Figure 1) is divided into a western Loei-Phetchabun Terrane and an eastern Truong Son Terrane (East Loei on Figure 1) separated by the Loei Suture.

(A) Ordovician in Truong Son Terrane in Laos based on Long et al. (2019). (B) Silurian to Early Devonian. Truong Son Terrane in Thailand and Laos. Thin fossiliferous limestones interbedded with shales and volcaniclastics interdigitate westwards with a volcanic island arc formed by eastward subduction of oceanic lithosphere. (C) Late Devonian (Givetian- Frasnian). Arc volcanism in central Loei Foldbelt (Panjasawatwong et al., 2006) with north-south ridges to the east in the Givetian with highly fossiliferous coral-stromatoporoid reefs overlying thin bedded limestones which overlie siliciclastics with plant material, trilobites, large brachiopods, and other benthos (Udchachon et al., 2017). (D) Famennian to earliest Tournaisian. Radiolarian cherts were deposited over much or most of the area (Saesaengseerung et al., 2007; Burrett et al., 2015). (E) Tournaisian. Initial docking of the Loei-Phetchabun and Truong Son terranes led to uplift of the over-riding block in the east and the deposition of a mainly turbiditic sequence of siliciclastics containing rare plant fragments in the west (Chairangsee et al., 1990). (F) Early Visean. Continued collision led to uplift of the over-riding block, metamorphism in the footwall area and the deformation of ophiolites in the Loei Suture and serpentinised ultramafics were squeezed close to the surface. Volcanism in the east provided volcanic material to coal deposits deposited further west. Other terrestrial deposits are evaporites and sandstones. (G) Early Permian. Continued erosion of the orogen led to the development of carbonate platforms during the mid-Visean separated by deeper marine basins such as the Nam Duk Basin. Deep-water siliciclastic and limestone turbidites in the Nam Duk Basin contain mafic detritus from the eroded Loei Suture to the 
FIGURE 14 | east. Rhyolites and dacites erupted across the eastern area from the Permian to the Triassic. (H) Early Triassic. Granites intruded across the area with associated widespread dacitic and rhyolitic volcanism. In the Early-Middle Triassic a second phase of folding was caused by docking of a terrane from the east-probably the Sukhothai Island Arc Terrane. A third phase of folding in the Late Triassic was probably caused by the collision of the combined Inthanon-Sibumasu Terrane with the amalgamated Indochina terranes during the Norian. Post-Norian terrestrial siliciclastics of the Khorat Group covered (and still cover) much of the area (Figure 3) and they were subsequently gently deformed in the Cretaceous due to the collision and indentation tectonics of India with Asia.

terminating at about $247 \mathrm{Ma}$ (Olenekian) (Lai et al., 2014; Liu et al., 2015; Xu et al., 2019; Xia et al., 2020). Liu et al. (2015) show that the ophiolitic mélange of the Ailaoshan suggests initial rifting and ocean opening in the Givetian through to the latest Carboniferous (Gzhelian). Thus, Ailaoshan may record a postcollision opening of the Ailaoshan Ocean between South China and Truong Son. However, Xia et al. (2016) and Xu et al. (2017) suggest an early Silurian rifting event thereby creating a problem for models such as that presented herein, requiring a late Silurian-Early Devonian collision along the whole Song Ma-Ailaoshan Belt. From these data it seems likely that the late Silurian to Devonian collision along Song Ma is not recorded in the Ailaoshan and may suggest that the Truong Son Terrane collision did not extend beyond Song Ma to Ailaoshan.

The collision of Truong Son with Kontum occurred along the Tamky Suture and possibly its continuation southward along the Poko Fault/Shear Zone (Figure 1). The Tamky Suture extends westwards into Laos where mapping by Hoffet (1937) near the town of Xepon ( $40 \mathrm{~km}$ southeast of the Sepon Mine) identified a $30 \mathrm{~km}$ wide east-west trending belt with gneiss flanked by granite to the south and then, further south, by dacite. Plagioclasebearing mylonitic gneisses from this belt near the Laos- Vietnam border yield a monazite age of $234+/-8 \mathrm{Ma}$ (Middle Triassic) (Nakano et al., 2013, p. 527). Movement and metamorphism along this gneiss belt may have started in the latest Permian or earliest Triassic (Lepvrier et al., 1997). Further north-west the Tamky Suture appears to merge with the Thakhek-Sepon Fault Zone that parallels the Mekong River (Figure 1). The Thakhek-Sepon Fault Zone is $630 \mathrm{~km}$ long and has a Pleistocene sinistral displacement of $3 \mathrm{~km}$ and a vertical displacement of $400 \mathrm{~m}$ (Thom et al., 2015) (Figure 3). Near Thakhek, terrestrial Cretaceous sandstones of the Nam Theun Group (= Khorat Group in Thailand) are uncharacteristically vertical as a result of movement along this fault and form the tourist attraction known locally as the "Great Wall." However, it is uncertain whether this fault is a Cenozoic reactivation of the western Palaeozoic margin of the Truong Son Terrane or whether it could be similar to the many major Cenozoic faults in mainland South East Asia related to Himalayan collision (Morley, 2002).

An alternative is that the Tamky Suture passes westwards under the Khorat Plateau as suggested in Figure 1. Tran et al. (2014) identified four deformation events in the Tamky Suture with D1 coeval with metamorphism and felsic magmatism at about $430 \mathrm{Ma}$ (mid-Silurian) and post D2 associated with magmatism and a proposed second continental collision at about 260-245 Ma (late Permian-Early Triassic). Poko Fault/Shear Zone (Figure 1) migmatites are intruded by unfoliated postD2 diorite dated by zircons as $255.6+/-3.4$ Ma-latest Permian (Tran et al., 2014) indicating little, if any, post-Permian deformation. Tran et al. (2014) propose that the mid-Silurian collision occurred when Kontum was part of the peri-Gondwana margin, though latest Ordovician to early Silurian mid-plate tholeiitic volcanics (as amphibolites) suggest that Kontum was already rifting-off by this time (Figure 13; Lan et al., 2003). A Silurian or Devonian collision of Kontum and Truong Son, as proposed by Wang et al. (2020), is unlikely as there is scant evidence of a widespread Silurian orogeny in the well-studied Sepon Mine section, which is $40 \mathrm{~km}$ north of the Tamky Suture (Thassanapak et al., 2018; Loydell et al., 2019). There is a stratigraphic inversion at the mine as Wenlock age limestone is structurally below Llandoverian graptolitic shale Figure 8). This is more likely to be due to accretion in an accretionary wedge rather than due to a major collisional orogeny. Overlying volcaniclastic submarine-fan deposits are coeval with Llandovery shales and contain plastically deformed (unindurated) shale clasts from the underlying graptolitic shale. The Llandoverian volcaniclastics and andesitic volcanics of the Sepon Mine area extend eastward to the Long Dai Volcanic Arc (Thassanapak et al., 2018; Loydell et al., 2019). The conformably overlying Silurian to Devonian shales and fine sandstones of the Kengkeuk Formation contain a moderately deep-water fauna, are gently deformed and unmetamorphosed, and show no evidence of a terrane collision.

Other than the influx of detrital material in the late Silurian and Middle Devonian in central Laos and Vietnam mentioned above, the major change in lithology is in the early Visean, in both the Sepon Mine area and $120 \mathrm{~km}$ further north in central Laos and in Vietnam (Thassanapak et al., 2012, 2018) (Figures 2, 7). The widespread, $350 \mathrm{~m}$ thick Boualapha Formation is Visean in age and extends throughout the region (Ban, 2000; Ban et al., $2000 \mathrm{a}, \mathrm{b})$ (Figures 11, 12) and is coeval with the lithologically similar Lakhe Formation in Vietnam (Figures 2, 4). In central Laos it consists of conglomerate, coarse sandstone, and minor limestone through to shales and is unconformable on Frasnian cherts and overlain by "mid"-Carboniferous (? late Visean, Khammouan Formation in Laos and the limestones of the basal Bac Son Formation in Vietnam) (Figures 2, 4). An open marine fauna of brachiopods, solitary rugose corals and trilobites is found in the Boualapha Formation and interdigitates with probably more restricted coastal sediments containing abundant bivalves (Ban, 2000; Nguyen, 2001; Thassanapak et al., 2012). To the south of the Sepon Mine area and close to but north of the Tamky Suture, coarse conglomerates and sandstones containing semi-anthracite (Figure 11) are probable but not certain, correlates of the Boualapha Formation. They appear from our reconnaissance mapping to be younger than deformed Late Devonian to Tournaisian limestones shown in Figures 9C-F, 10. These deformed limestones show features suggesting shallowing and karstification during uplift during the proposed collision of the Truong Son and Loei-Phetchabun terranes. In the 


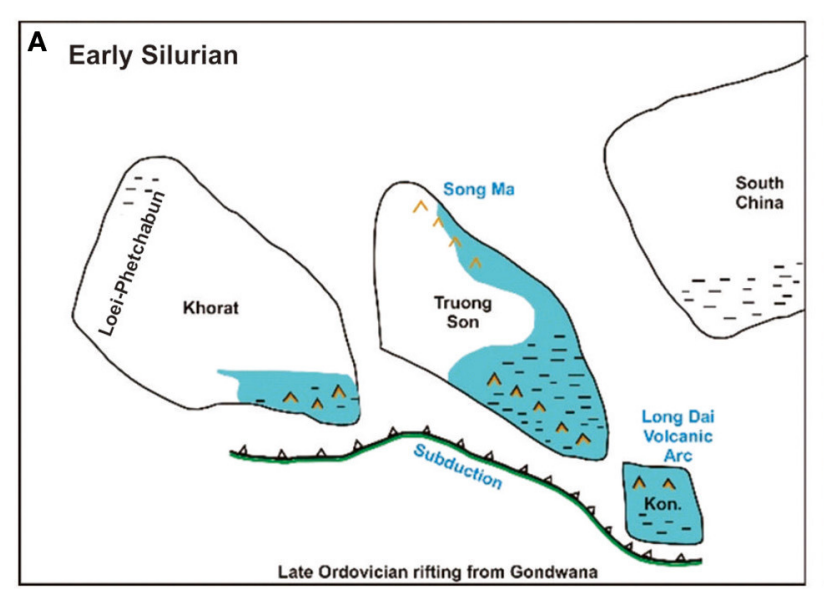

\section{B Early Carboniferous}
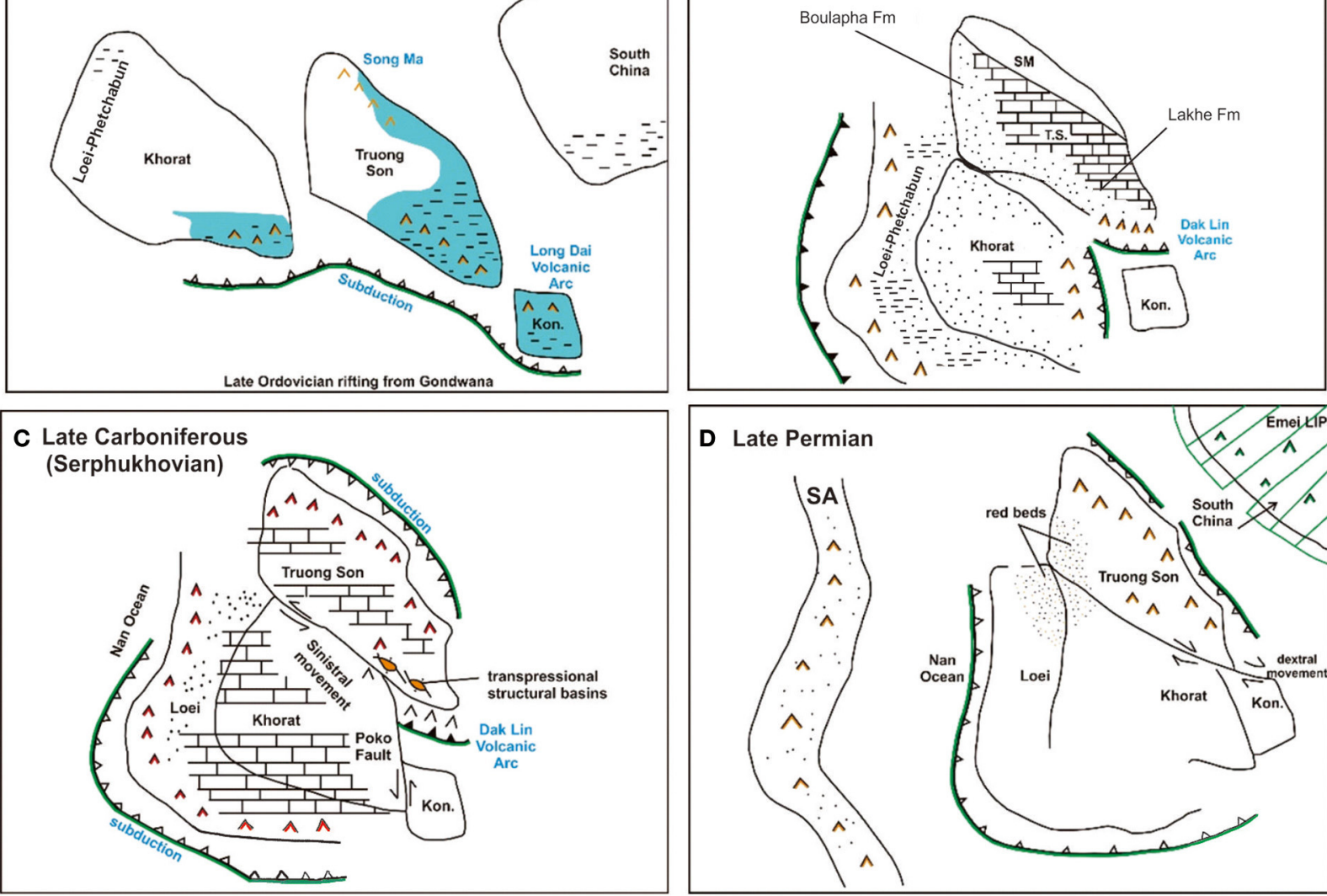

D Late Permian

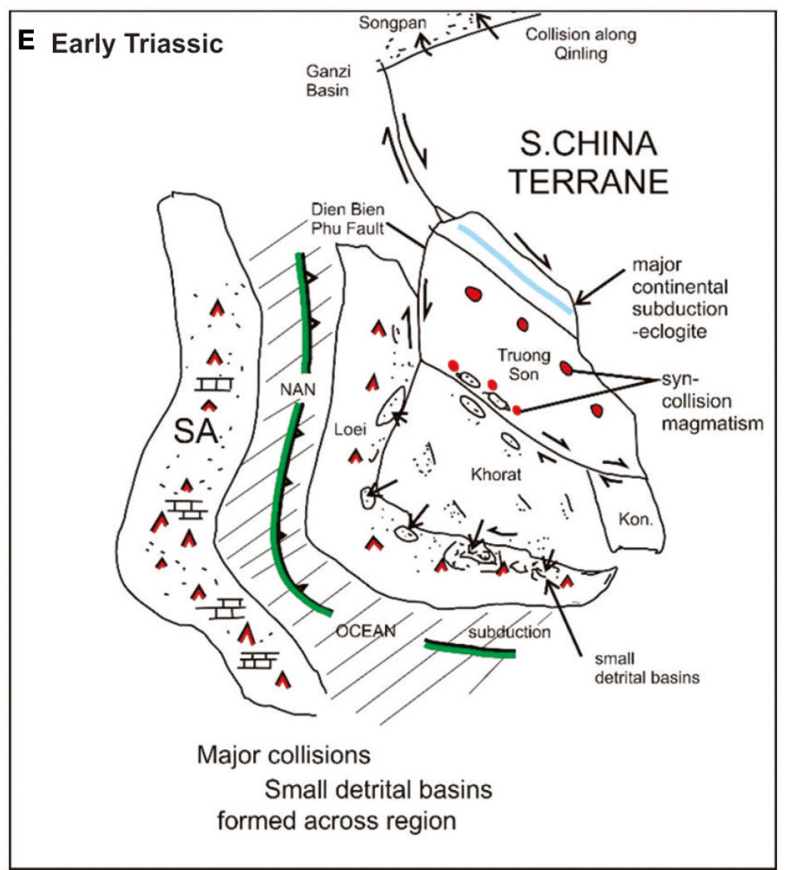

FIGURE 15 | Speculative palaeogeographic sketches showing suggested rifting, convergence, and fusion of the Truong Son, Loei-Phetchabun, and Kontum terranes. Kon, Kontum Terrane; LDV, Long Dai Volcanic Arc (late Ordovician to Silurian); SA, Sukhothai Terrane (Permo-Triassic volcanic arc-see Figure 1), and TR, 
FIGURE 15 | Truong Son Terrane. (A) Early Silurian with terranes having just rifted from Gondwana. (B) Early Carboniferous (late Tournaisian to earliest Visean) - initial collision of Loei-Phetchabun and Truong Son terranes, with influx of siliciclastics, including some coarse conglomerates. (C) Late Carboniferous - just after collision of Truong Son and Loei-Phetchabun terranes in the Serphukovian. Deposition of Wang Saphung Formation in Loei region and the establishment of a carbonate platform in the Visean across both the Loei-Phetchabun and Truong Son terranes in Laos, Vietnam, NE Thailand and possibly in Cambodia. Possible initial docking of Kontum Terrane with Loei-Phetchabun terrane along Poko Fault. (D) Late Permian. Kontum Terrane collides with Truong Son and Loei-Phetchabun terranes with stitching pluton across Poko Fault. (E) Early- Middle Triassic collision of the Sukhothai Island Arc Terrane and subsequent transcurrent fault movements led to the creation of numerous small basins, often half graben and filled with volcaniclastics, lacustrine, and fluviatile sediments. Final assembly of most mainland SE Asian terranes except for the West Burma Terrane occurred in the Norian.

Loei-Phetchabun Terrane, in the Loei Foldbelt, a similar influx of coarse terrigenous material bearing plant material (Figures 8D-F) and associated with semi-anthracite deposits occurred along with major deformation, in the late Tournaisian to early Visean, terminating deep-water chert sedimentation and giving way to later Visean to mid-Permian platform limestone successions (Chairangsee et al., 1990; Ratanasthien, 2011; Udchachon et al., 2017, their Figure 13).

A "mid-Carboniferous" unconformity is recognized in the five petroleum wells that have penetrated beneath the Pennsylvanian Si That Formation on the Khorat Plateau and is picked on many seismic sections (Figures 3, 4) (Booth and Sattayarak, 2011). Two of the wells encountered granites, one of which at Yang Talat (Figures 3, 4) is dated at 329+/-3 Ma ("mid"-Carboniferous). We therefore suggest that the fusion of the Truong Son and LoeiPhetchabun Terranes took place in the late Tournaisian to early Visean (Figures 2, 14, 15). The four plutons dated as $332 \mathrm{Ma}$ (late Visean) that are widespread in western Cambodia (Cheng et al., 2019) may be the result of this collision.

The widespread Visean-initiated, post-orogenic, carbonate platform was terminated in the Truong Son and Loei-Phetchabun terranes mainly in the mid-Permian and is replaced by marginal marine to terrestrial siliciclastics. However, in some areas, such as in the Phetchabun Province, carbonate sedimentation continued until the late Permian (Wuchiapingian) (Hada et al., 2020). Generally, terrestrial to marginal marine siliciclastic deposition, continued from the late Permian to the Cretaceous with minor Triassic and Jurassic marine limestones on Truong Son and on Sibumasu. Speculatively, the early Norian Indosinian I/II events picked on seismic sections (Booth and Sattayarak, 2011) may be due to the collision of South China and Truong Son possibly subsequent to the deeply subducted eclogite of the Song Ma Suture at about 233 Ma (Nakano et al., 2008, 2010). The Indosinian III Unconformity was probably due to the final consolidation of the terranes in the late Norian with the closure of the Nan Suture and the collision of Sukhothai, Inthanon, and Sibumasu terranes (Chaodumrong and Burrett, 1997; Hirsch et al., 2006; Barber et al., 2011; Kamata et al., 2013; Arboit et al., 2016; Hara et al., 2021).

\section{CONCLUSIONS}

Mainland South East Asia consists of at least three geologically distinct terranes-the Loei-Phetchabun, Truong Son, and Kontum, and some of their defining characteristics are summarized in Table 1. Complex sedimentological, magmatic, structural, and metamorphic histories make a realistic model for their tectonic development speculative. However, by synthesizing data from diverse sources, much of it accumulated in the last 10 years, we propose a preliminary tectonic hypothesis for the rift, drift, and fusion of the Indochina terranes (Figures 2-5, 7, 14, 15). The Truong Son Terrane rifted from the MiddleEast-Himalayan sector in the Late Ordovician and the Kontum Terrane rifted from the western Australian sector also in the latest Ordovician or early Silurian (Figure 15). There is no evidence for the time of rifting of the Loei-Phetchabun Terrane. The Truong Son and Loei-Phetchabun terranes have distinct geological histories prior to the Visean (Figures 2, 5, 14). Sedimentologically, the Frasnian to Tournaisian carbonate platform of Truong Son and the siliciclastic marine platform of Loei-Phetchabun were terminated in the latest Tournaisian to earliest Visean by influxes of coarse siliciclastics, the closure of the Loei Suture, uplift, subsequent strong deformation, and the development of terrestrial deposits (Figures 2-4). By the middle Visean, erosion allowed the development of a tropical carbonate platform across both terranes which was terminated in the midlate Permian (Figures 2-5, 14). It is suggested that the Loei Suture separated the Truong Son and Loei-Phetchabun terranes and is defined by the Loei thrust fault, serpentinites, chrome spinels, and recently discovered ultramafics (Figures 1, 2, 6, 15). A long-lasting ocean is indicated along the Nan Suture from the Late Ordovician to the Triassic based on recent dating of gabbros and basalts (Shen et al., 2010a; Khin et al., 2014) (Figures 2, 14, 15). Subduction of oceanic lithosphere led to arc magmatism along the western margin of the Loei-Phetchabun Terrane from the Devonian (Intasopa and Dunn, 1994; Panjasawatwong et al., 2006) and along the western and southern margins of the combined terranes until the Triassic (Shen et al., 2010b; Barr and Charusiri, 2011; Salam et al., 2014; Qian et al., 2015) (Figure 15). Collision of the combined Sibumasu-Inthanon Terranes with the combined Indochina terranes in the late Triassic (NorianRhaetic) finalized the fusion of most of the mainland SE Asian terranes.

\section{AUTHOR CONTRIBUTIONS}

All authors contributed equally to the writing of the paper.

\section{ACKNOWLEDGMENTS}

We thank numerous geologists in many countries for their help over many years and the two journal reviewers and the guest 
editor Professor BT whose comments have greatly improved the manuscript. We thank Mahasarakham University and the Department of Geology and Minerals, Laos, the Department of Mineral Resources, Bangkok and LXML Company (Sepon) for fieldtrips, information, and support. This is a contribution to IGCP 668 Equatorial Gondwana History and Early Paleozoic Evolutionary Dynamics and IGCP 700 Carbonate Build-ups in South East Asia.

\section{REFERENCES}

Arboit, F., Collins, A. S., Morley, C. K., King, R., and Amrouch, K. (2016). Detrital zircon analysis of the southwest Indochina terrane, central Thailand: unravelling the Indosinian orogeny. Geol. Soc. Am. Bullet. 128:B31411.1. doi: 10.1130/B31411.1

Badarch, G., Cunningham, W. D., and Windley, B. F. (2002). A new terrane subdivision for Mongolia: implications for the Phanerozoic crustal growth of Central Asia. J. Asian Earth Sci. 21, 87-110. doi: 10.1016/S1367-9120(02)00017-2

Ban, Tran, Van, Vu, D. C., Le, V. D., Tran, S., TA, Q. D., Phengthavongsa, B., Vilayhack, S., et al. (2000a). Geological Map of Khamkeut, Sheet e-48, 1: 200,000. Hanoi: Lao PDR Department of Geology and Mines Vientiane and INTERGEO.

Ban, Tran, Van, Vu, D. C., Le, V. D., Tran, S., TA, Q. D., Phengthavongsa, B., Vilayhack, S., et al. (2000b). Geological Map of Nape, Sheet e-48 XVI, 1: 200,000. Hanoi: Lao PDR Department of Geology and Mines Vientiane and INTERGEO.

Ban, T. V. (2000). Report on the Geology and Minerals of Mid-Central Laos Region. Final Report. Part 1 General Geology. Hanoi: Lao PDR Department of Geology and Mines. Vientiane and INTERGEO.

Barber, A. J., Ridd, M., and Crow, M. J. (2011). "The origin, movement and assembly of pre-Tertiary tectonic units of Thailand," in The Geology of Thailand, eds M. F. Ridd, A. J. Barber, and M. J. Crow (London: Geological Society), 507-538. doi: 10.1144/GOTH.19

Barr, S. M., and Charusiri, P. (2011). "Volcanic rocks," in The Geology of Thailand, eds M. F. Ridd, A. J. Barber, and M. J. Crow (London: Geological Society), 415-439. doi: 10.1144/GOTH.15

Barr, S. M., and MacDonald, A. S. (1991). Toward a Late Paleozoic-Early Mesozoic tectonic model for Thailand. Thailand J. Geosci. 11-22.

Barr, S. M., Tantisukrit, C., Yaowanoiyothin, W., and Macdonald, A. S. (1990). Petrology and Tectonic implications of upper Paleozoic volcanic rocks of Chiang Mai Belt, northern Thailand. J. Southeast Asian Earth Sci. 4, 37-47. doi: 10.1016/0743-9547(90)90023-7

Booth, J., and Sattayarak, N. (2011). "Subsurface Carboniferous-Cretaceous of NE Thailand," in The Geology of Thailand, eds M. F. Ridd, A. J. Barber, and M. J. Crow (London: Geological Society), 185-222. doi: 10.1144/GOTH.9

Brown, G. F. (1951). Geologic reconnaissance of the mineral deposits of Thailand. US Geol. Survey Bullet. 984, 1-185.

Bunopas, S. (1982). Palaeogeographic History of Western Thailand and Adjacent Parts of Southeast Asia. Geological Survey of Thailand Paper 5. Royal Thai Department of Mineral Resources, Bangkok, Thailand.

Burrett, C., Khin, Z., Meffre, S., Lai, C., Khositanont, S., Chaodumrong, P., et al. (2014a). The configuration of Greater Gondwana-Evidence from LA ICPMS U-Pb geochronology of detrital zircons from the Palaeozoic and Mesozoic of Southeast Asia and China. Gondwana Res. 26, 31-51. doi: 10.1016/j.gr.2013.05.020

Burrett, C., Stait, B. A., Sharples, C., and Laurie, J. (1984). "Middle-Upper Ordovician shallow platform to deep basin transect, southern Tasmania, Australia," in Aspects of the Ordovician System, ed D. L. Bruton. (Oslo: Universitetsforlaget), 149-158.

Burrett, C., Thassanapak, H., and Udchachon, M. (2015). Upper Devonian (Famennian) conodonts from radiolarian cherts, Loei Terrane, Loei Province, Northeast Thailand. Res. Knowled. 1, 26-32. doi: 10.14456/randk.2 015.14

Burrett, C., Udchachon, M., Thassanapak, M., and Chitnarin, A. (2014b). Conodonts, radiolarians and ostracodes in the Permian E-Lert Formation, Loei Fold Belt, Indochina Terrane, Thailand. Geol. Magazine 152, 106-142. doi: $10.1017 /$ S001675681400017X

Cannell, J., Stewart, J., Williams, P., Wallace, M., Burrett, C., and Davis, B. (2015). "The Sepon copper deposits (Laos) and their relation to Carlin-like

gold mineralisation," in Proceedings of the PACRIM Congress 2015 (Hong Kong: Australian Institute of Mining and Metallurgy), 1-10.

Chairangsee, C., Hinze, C., Macharoensap, S., Nakornsri, N., Silpalit, M., and Sinpool-Arunt, S. (1990). Geological map of Thailand 1;50,000, explanation for the sheets Amphoe Pak Chom, Ban Na Kho, Ban Huai Khop, Nam Som. Geologisch. Jahrbuch Reihe A 73, 3-55.

Chaodumrong, P., and Burrett, C. (1997). "Early Late Triassic continental collision between Shan-Thai and Indochina Terranes as indicated by the occurrence of fan delta deposits of the Pha Daeng Formation, Central North Thailand," in P. Dheeradilok, C. Hintong, eds, Proceedings of the International Conference on Stratigraphy and Tectonic Evolution of Southeast Asia and the South Pacific (GEOTHAI 97) (Bangkok), 143-157.

Charusiri, P., Daorerk, V., Archibold, D., Hisada, K., and Ampaiwan, T. (2002). Geotectonic evolution of Thailand: a new synthesis. J. Geol. Soc. Thailand 2002, 1-20.

Cheng, R., Uchida, E., Katayose, M., Yarimizu, K., Shin, K. C., Kong, S., et al. (2019). Petrogenesis and tectonic setting of Late Paleozoic to Late Mesozoic igneous rocks in Cambodia. J. Asian Earth Sci. 185:104046. doi: 10.1016/j.jseaes.2019.104046

Cocks, L. R. M., and Torsvik, T. (2013). The dynamic evolution of the Palaeozoic geography of eastern Asia. Earth Sci. Rev. 117, 40-79. doi: 10.1016/j.earscirev.2012.12.001

De, Le V. (1997). "Outline of plate-evolution of continental crust of Vietnam," in Proceedings of the International Conference on the Stratigraphy and Tectonic evolution of Southeast Asia and the South Pacific, Volume 2, ed P. Dheeradilok (Bangkok: Department of Mineral Resources), 465-474.

Faure, M., Nguyen, V. V., Hoai, L. T. T., and Lepvrier, C. (2018). Early Paleozoic or early-middle Triassic collision between the South China and indochina blocks: the controversy resolved? Structural insights from the Kon Tum massif (Central Vietnam). J. Asian Earth Sci. 166, 162-180. doi: 10.1016/j.jseaes.2018. 07.015

Findlay, R. H. (1997). The Song Ma Anticlinorium, northern Vietnam: the structure of an allochthonous terrane containing an early Palaeozoic island arc sequence. J. Asian Earth Sci. 15, 453-464. doi: 10.1016/S0743-9547(97) 00031-7

Findlay, R. H., and Trinh, P. T. (1997). The structural setting of the Song Ma region, Vietnam and the Indochina plate boundary problem. Gondwana Res. 1, 11-33. doi: 10.1016/S1342-937X(05)70003-4

Fontaine, H., Salyapongse, S., Suteethorn, V., Tian, P., and Vachard, D. (2005). Sedimentary Rocks of the Loei Region, Northeast Thailand: Stratigraphy, Paleontology, and Sedimentology. Bangkok: Bureau of Geological Survey, Department of Mineral Resources.

Fromaget, J. (1927). Études géologiques sur le Nord de l'Indochine centrale: Impr. d'Extrême-Orient. Bulletin du Service Géologique de l'Indochine 16, 1-386.

Fromaget, J. (1941). L'Indochine Francaise, sa structure geologique, ses roches, ses mines et leur relation possible avec la tectonique. Bulletin du Service Géologique de l'Indochine 26, 1-267.

Gardner, C. J., Graham, I. T., Belousova, E., Booth, G. W., and Greig, A. (2017). Evidence for Ordovician subduction-related magmatism in the Truong Son terrane, SE Laos: implications for Gondwana evolution and porphyry $\mathrm{Cu}$ exploration potential in SE Asia. Gondwana Res. 44, 139-156. doi: 10.1016/j.gr.2016.11.003

Genovese, L. (2011). Madeleine Colani and the Deprat scandal at the Geological Survey of Indochina. J. Siam Soc. 99, 269-290.

Hada, S., Khosithanont, S., and Goto, H. (2020). A remarkable end-Permian boulder bed of conglomeratic limestone at Nam Nao, NE Thailand: its biostratigraphical and environmental significance. Thai Geosci. J. 1, 1-16. doi: $10.14456 /$ tgi.2020.1

Hara, H., Tokiwa, T., Kurihara, T., Charoentitirat, T., and Sardsud, A. (2021). Revisiting the tectonic evolution of the Triassic Palaeo-Tethys convergence 
zone in northern Thailand inferred from detrital zircon $\mathrm{U}-\mathrm{Pb}$ ages. Geol. Magazine 158, 905-925. doi: 10.1017/S0016756820001028

Hieu, P. T., Li, S-Q., Yu, Y., Thanh, N. X., Dung, L. T., Tu, V. L., et al. (2017). Stages of late Paleozoic to early Mesozoic magmatism in the Song Ma belt, NW Vietnam: evidence from zircon $\mathrm{U}-\mathrm{Pb}$ geochronology and $\mathrm{Hf}$ isotope composition. Int. J. Earth Sci. 106, 855-874. doi: 10.1007/s00531-016-1337-9

Hieu, P. T., Yang, Y-Z., Binh, D. Q., Nguyen, T. B. T., Dung, L. T., and Chen, F. (2015). Late Permian to Early Triassic crustal evolution of the Kontum massif, central Vietnam: zircon $\mathrm{U}-\mathrm{Pb}$ ages and geochemical and $\mathrm{Nd}-\mathrm{Hf}$ isotopic composition of the Hai Van granitoid complex. Int. Geol. Rev. 57, 1877-1888. doi: 10.1080/00206814.2015.1031194

Hirsch, F., Ishida, K., Kozai, T., and Meesook, A. (2006). The welding of ShanThai. Geosci. J. 10, 195-204. doi: 10.1007/BF02910364

Hoffet, J. (1937). Note sur la geologie du Bas Laos. Bulletin du Service Geologique de l'Indochine 24, 1-23.

Howell, D. G. (1980). Mesozoic accretion of exotic terranes along the New Zealand segment of Gondwanaland. Geology 8, 487-491. doi: 10.1130/ 0091-7613(1980)8<487:MAOETA > 2.0.CO;2

Howell, D. G. (1989). Tectonics of Suspect Terranes: Mountain Building and Continental Growth. London: Chapman and Hall. doi: 10.1007/978-94-010-9824-3

Howell, D. G., Jones, D. L., and Schermer, E. R. (1985). “Tectonostratigraphic terranes of the Circum-Pacific region," in Tectonostratigraphic Terranes of the Circum-Pacific Region, Earth Science Series, ed D. G. Howell (Houston, TX: Council for Energy and Mineral Resources), 3-30.

Howell, K., and Howell, D. G. (1995). Principles of Terrane Analysis: New Applications for Global Tectonics. New York, NY; Houston, TX: Chapman and Hall.

Intasopa, S., and Dunn, T. (1994). Petrology and Sr-Nd isotopic systems of the basalts and rhyolites, Loei, Thailand. J. Southeast Asian Earth Sci. 9, 167-180. doi: 10.1016/0743-9547(94)90073-6

Izokh, A., Hoa, T. T., Phuong, N. T., and Hung, T. Q. (2006). Ophiolite ultramaficmafic associations in the northern structure of the Kun Tum block (central Vietnam). J. Geol. Ser. B 28, 20-26.

Janvier, P., and Thanh, T-D. (1998). The Silurian and Devonian vertebrates of Viêt Nam: a review. J. Geol. Ser. B, 18-28.

Janvier, P., Thanh, T. D., Phuong, T. H., and Truong, D. N. (1997). The Devonian vertebrates (Placodermi, Sarcopterygii) from Central Vietnam and their bearing on the Devonian palaeogeography of Southeast Asia. J. Asian Earth Sci. 15, 393-406. doi: 10.1016/S0743-9547(97)00020-2

Kamata, Y., Shirouzu, A., and Ueno, K. (2013). Late Permian and Early to Middle Triassic radiolarians from the Hat Yai area, southern peninsular Thailand: Implications for the tectonic setting of the eastern margin of the Sibumasu Continental Block and closure timing of the Paleo-Tethys. Marine Micropaleontol. 110, 8-24. doi: 10.1016/j.marmicro.2013.07.006

Kamvong, T., Khin, Z., Meffre, S., Maas, R., Stein, H., and Lai, C. (2014). Adakites in the Loei and Truongson Belts, Thailand and Laos: genesis and implications for geodynamics and metallogeny. Gondwana Res. 26, 165-184. doi: 10.1016/j.gr.2013.06.011

Khin, Z., Meffre, S., Lai, C., Burrett, C., Santosh, M., Graham, I., et al. (2014). Tectonics and metallogeny of mainland Southeast Asia- a review and contribution. Gondwana Res. 26, 5-30. doi: 10.1016/j.gr.2013.10.010

Khositanont, S., Khin, Z., Meffre, S., Panjasawatwong, Y., Ouchanum, P., and Thanasutihipak, T. (2013). "Geotectonic and geochronology of volcanoplutonic rocks in the Loei Phetchabun foldbelt," in Proceedings of the 2nd Lao-Thai Technical Conference on Geology and Mineral Resources, eds C. Senebouttalath, P. Robang (Vientiane: Department of Geology and Minerals), 81-95.

Lai, C., Meffre, S., Crawford, A. J., Khin, Z., Xue, C., and Halpin, J. A. (2014). The Western Ailaoshan Volcanic Belts and their SE Asia connection: a new tectonic model for the Eastern Indochina block. Gondwana Res. 26, 52-74. doi: 10.1016/j.gr.2013.03.003

Lan, C., Chung, S., Long, T. V., Lo, C. H., Lee, T. Y., Mertzman, S., et al. (2003). Geochemical and Sr-Nd isotopic constraints from the Kontum Massif, central Vietnam on the crustal evolution of the Indochina Block. Precambrian Res. 122, 7-27. doi: 10.1016/S0301-9268(02)00205-X

Lepvrier, C., Maluski, H., Nguyen, V. V., Roques, D., Axente, V., and Rangin, C. (1997). Indosinian NW trending shear zones within the Truong Son belt (Vietnam). Tectonophysics 283, 105-127. doi: 10.1016/S0040-1951(97)0 0151-0

Lepvrier, C., Maluski, H., Tich, V. V., Phan, T. T., and Nguyen, V. V. (2004) The Early Triassic Indosinian orogeny in Vietnam (Truong Son belt and Kontum Massif): implications for the geodynamic evolution of Indochina. Tectonophysics 303, 87-118. doi: 10.1016/j.tecto.2004.07.030

Lepvrier, C., Nguyen, V. V., Maluski, H., Phan, T. T., and Tich, V. V. (2008). Indosinian tectonics in Vietnam. Comptes. Rendu Geosci. 340, 94-111. doi: 10.1016/j.crte.2007.10.005

Lin, Y. L., Yeh, M., Lee, T., Chung, S., Iizuka, Y., and Charusiri, P. (2013). First evidence of the Cambrian basement in Upper Peninsula of Thailand and its implication for crustal and tectonic evolution of the Sibumasu Terrane. Gondwana Res. 24, 1031-1037. doi: 10.1016/j.gr.2013.05.014

Liu, H., Wang, Y., Cawood, P., Fan, W., Cai, Y., and Xing, X. (2015). Record of Tethyan ocean closure and Indosinian collision along the Ailaoshan Suture (SW China). Gondwana Res. 27, 198-230. doi: 10.1016/j.gr.2013.12.013

Liu, J., Tran, M. D., Tang, Y., Nguyen, Q. L., Tran, T. H., Wu, W., et al. (2012). Permo-Triassic granitoids in the northern part of the Truong Son belt, NW Vietnam: geochronology, geochemistry and tectonic implications. Gondwana Res. 22, 628-644. doi: 10.1016/j.gr.2011.10.011

Long, Y., Zhang, D., Huang, D., Yang, X., Chen, S., and Bayless, R. C. (2019). Age composition and tectonic implications of late Ordovician-early Silurian igneous rocks of the Loei volcanic Belt, NW Laos. Int. Geol. Rev. 61, 1940-1956. doi: 10.1080/00206814.2019.1576065

Loydell, D., Udchachon, M., and Burrett, C. (2019). Llandovery (lower Silurian) graptolites from the Sepon Mine, Truong Son Terrane, central Laos and their palaeogeographical significance. J. Asian Earth Sci. 170, 360-374. doi: 10.1016/j.jseaes.2018.11.013

Maluski, H., Lepvrier, C., Leyreloup, A., Tich, V. V., and Thi, P. T. (2005). Ar-Ar geochronology of the charnockites and granulites of the Kan Nack complex, Kon Tum Massif, Vietnam. J. Asian Earth Sci. 25, 653-677. doi: 10.1016/j.jseaes.2004.07.004

Manaka, T., Khin, Z., Meffre, S., Vasconcelos, P., and Golding, S. (2014). The Ban Houayxai epithermal Au-Ag deposit in northern Lao PDR: mineralization related to the Early Permian arc magmatism of the Truong Son Fold belt. Gondwana Res. 26, 185-197. doi: 10.1016/j.gr.2013.08.024

Metcalfe, I. (1984). Stratigraphy, palaeontology and palaeogeography of the Carboniferous of Southeast Asia. Memoires Societe Geologiques France $147,107-118$.

Metcalfe, I. (2021). Multiple Tethyan Ocean basins and orogenic belts in Asia Gondwana Res. 1:12. doi: 10.1016/j.gr.2021.01.012

Minezaki, T., Hisada, K., Hara, H., and Kamata, Y. (2019). Tectonostratigraphy of Late Carboniferous to Triassic successions of the Khorat Plateau Basin, Indochina Block, Northeastern Thailand: Initiation of the Indosinian Orogeny by collision of the Indochina and South China Blocks. J. Asian Earth Sci. 170, 208-224. doi: 10.1016/j.jseaes.2018.10.020

Morley, C. K. (2002). A tectonic model for the Tertiary evolution of strike-slip faults and rift basins in SE Asia. Tectonophysics 347, 189-215. doi: 10.1016/S0040-1951(02)00061-6

Morley, C. K., Ampaiwan, P., Thanudamrong, S., Kuenphan, N., and Warren, J. (2013). Development of the Khao Khwang Fold and Thrust Belt: Implications for the geodynamic setting of Thailand and Cambodia during the Indosinian Orogeny. J. Asian Earth Sci. 63, 705-719. doi: 10.1016/j.jseaes.2012. 11.021

Mouret, C. (1994). "Geological history of northeastern Thailand since the Carboniferous relation with Indochina and Carboniferous-Early Cenozoic evolution model," in Proceedings of the International Symposium on Stratigraphic Correlation of Southeast Asia, eds P. Angsuwathana, T. Wongwanich, W. Tansathien, S. Wongsomsak, and J. Tulyatid (Bangkok: Department of Mineral Resources), 132-158.

Nakano, N., Osanai, Y., and Nguyen, T. M. (2008). Discovery of high-pressure granulite metamorphism in northern Vietnam: constraints on Permo-Triassic Indochinese continental collision tectonics. Comptes. Rendu Geoscience 340, 127-138. doi: 10.1016/j.crte.2007.10.013

Nakano, N., Osanai, Y., Owada, M., Hayasaka, Y., and Nam, T. N. (2009). PermoTriassic Barrovian-type metamorphism in the ultrahigh-temperature Kontum Massif, central Vietnam. Constraints on continental collision tectonics in South East Asia. Island Arc. 18, 126-143. doi: 10.1111/j.1440-1738.2008.00646.x 
Nakano, N., Osanai, Y., Owada, M., Nam, T. N., Charusiri, P., and Khamphavaong, K. (2013). Tectonic evolution of high grade metamorphic terranes in central Vietnam: constraints from large scale monazite geochronology. J. Asian Earth Sci. 73, 520-539. doi: 10.1016/j.jseaes.2013. 05.010

Nakano, N., Osanai, Y., Owada, M., Nam, T. N., Tokoshima, T., Binh, P., et al. (2007). Geologic and metamorphic evolution of the basement complexes in the Kontum Massif, central Vietnam. Gondwana Res. 12, 438-453. doi: 10.1016/j.gr.2007.01.003

Nakano, N., Osanai, Y., Owada, M., Pham, B., Kaiden, H., and Buie, V. T. S. (2020). Evolution of the Indochina Block from its formation to amalgamation with Asia: constraints from protoliths in the Kontum Massif, Vietnam. Gondwana Res. 11:2. doi: 10.1016/j.gr.2020.11.002

Nakano, N., Osanai, Y., Sajeev, K., Hayasaka, Y., Miyamoto, T., Minh, N. T., et al. (2010). Triassic eclogite from northern Vietnam: inferences and geological significance. J. Metamorphic Geol. 28, 59-76. doi: 10.1111/j.1525-1314.2009.00853.x

Nguyen, H. H. (2001). Astrorhizae-like structures on epitheca of rugose corals from the Carboniferous of Laos. Acta Palaeontol. Polonica 46, 583-588.

Nguyen, Q. M., Feng, Q., Zi, J., Zhao, T., Tran, H. T., Ngo, T. X., et al. (2019). Cambrian intra-oceanic arc trondhjemite and tonalite in the Tam Ky-Phuoc Son Suture Zone, central Vietnam: implications for the early Paleozoic assembly of the Indochina Block. Gondwana Res. 70, 151-170. doi: 10.1016/j.gr.2019.01.002

Osanai, Y., Nakano, N., Owada, M., Nam, T. N., Toyoshima, T., Tsunogae, T., et al. (2004). Permo-Triassic ultrahigh-temperature metamorphism in the Kontum Massif, central Vietnam. J. Mineral. Petrol. Sci. 99, 225-241. doi: $10.2465 /$ jmps. 99.225

Panjasawatwong, Y., Khin, Z., Chantramee, S., Limtrukun, P., and Pirarai, K. (2006). Geochemistry and tectonic setting of the Central Loei volcanic rocks Pak Chom area, Loei, northeastern Thailand. J. Asian Earth Sci. 26, 77-90. doi: 10.1016/j.jseaes.2004.09.008

Qian, X., Feng, Q., Yang, W., Wang, Y., Chonglakmani, C., and Monjai, D. (2015). Arc-like volcanic rocks in NW Laos: geochronological and geochemical constraints and their tectonic implications. J. Asian Earth Sci. 98, 342-350 doi: 10.1016/j.jseaes.2014.11.035

Ratanasthien, B. (2011). "Coal Deposits," in The Geology of Thailand, eds M. F. Ridd, A. J. Barber, and M. J. Crow (London: Geological Society), 394-414.

Saesaengseerung, D., Sashida, K., and Sardsud, A. (2007). Late Devonian to Early Carboniferous radiolarian fauna from the Pak Chom area, Loei Province, northeastern Thailand. Palaeontol. Res. 11, 109-121. doi: 10.2517/13428144(2007)11[109:LDTECR]2.0.CO;2

Salam, A., Khin, Z., Meffre, S., McPhie, J., and Lai, C. (2014). Geochemistry and geochronology of epithermal Au-hosted Chatree volcanic sequence: implications for tectonic setting of the Loei Fold belt in central Thailand. Gondwana Res. 26, 198-217. doi: 10.1016/j.gr.2013.10.008

Sanematsu, K., Murakami, H., Duangsurigna, S., Vilayhack, S., Duncan, R., and Watanabe, Y. (2011). Ar-Ar ages of granitoids from the Truong Son fold belt and Kontum massif in Laos. J. Mineral. Petrol. Sci. 106, 13-25. doi: 10.2465/jmps.091216

Shen, S., Feng, Q., Yang, W., Zhang, Z., and Chonglakmani, C. (2010a). Study on the geochemical characteristics of ocean-ridge and ocean island volcanic rocks in the Nan-Uttaradit zone, northern Thailand. Chin. J. Geochem. 29, 175-181. doi: 10.1007/s11631-010-0175-X

Shen, S., Feng, Q., Yang, W., Zhang, Z., and Chonglakmani, C. (2010b). Geochemical characteristics of island arc volcanic rocks in the Nan-Nan Pat-Phetchabun zone, northern Thailand, Chin. J. Geochem. 29, 337-342. doi: 10.1007/s11631-010-0465-3

Shi, M., Lin, F., Fan, W., Deng, Q., Cong, F., Tran, M. D., et al. (2015). Zircon U$\mathrm{Pb}$ ages and geochemistry of granitoids in the Truong Son terrane Vietnam: tectonic and metallogenic implications. J. Asian Earth Sci. 101, 101-120. doi: 10.1016/j.jseaes.2015.02.001

Thanh, N. X., Hai, T. T., Nguyen H., La, V. Q., Kwon, S., Itaya, T., et al. (2014). Backarc mafic-ultramafic magmatism in Northeastern Vietnam and its regional tectonic significance. J. Asian Earth Sci. 90, 45-60. doi: $10.1016 /$ j.jseaes.2014.04.001

Thanh, N. X., Tu, M. T., Itaya, T., and Kwon, S. (2011). Chromium-spinel composition from the Bo Xinh utramafics, Northern Vietnam: implications on tectonic evolution of the Indochina Block. J. Asian Earth Sci. 42, 258-267. doi: 10.1016/j.jseaes.2011.02.004

Thanh, T. D., Duyen, T. D., Hung, N. H., and My, B. P. (2007). Discovery of the fossiliferous $\mathrm{Cu}$ Brei Formation (Lower Devonian) in the Kon Tum Block (South Vietnam). J. Asian Earth Sci. 29, 127-135. doi: 10.1016/j.jseaes.2006.02.006

Thanh, T. D., Janvier, P., and Phuong, T. H. (1996). Fish suggest continental connection between the Indochina and South China Blocks in Middle Devonian time. Geology 24, 571-574. doi: 10.1130/00917613(1996)024<0571:FSCCBT>2.3.CO;2

Thanh, T. D., Phuong, T. H., Boucot, A. J., Goujet, D., and Janvier, P. (1997). Silurian vertebrates from Central Vietnam. Comptes Rendus de l'Académie des Sciences Série II a 324, 1023-1030.

Thassanapak, H., Udchachon, M., and Burrett, C. (2012). Devonian radiolarians and tentaculitids from Central Laos. J. Asian Earth Sci. 60, 104-113. doi: 10.1016/j.jseaes.2012.08.002

Thassanapak, H., Udchachon, M., and Burrett, C. (2018). Silurian radiolarians from the Sepon Mine, Truong Son Terrane, central Laos and their palaeogeographic and tectonic significance. Geol. Magazine 155, 1621-1640. doi: 10.1017/S0016756817000425

Thom, B. V., Nguyen, V. H., Sunlinthone, O., Duangpaseuth, S., and Markvilay, B. (2015). Dac Diem doi dut gay hoat dong Thakhet-Sepon (Characteristics of the Thakhet-Sepon active fault zone). Tap chí Các Khoa họ vê Trái Đt Vietnam J Earth Sci. 37, 36-47. doi: 10.15625/0866-7187/37/1/6551

Torsvik, T. H., and Cocks, L. R. M. (2009). "The Lower Palaeozoic palaeogeographical evolution of the northeastern and eastern peri-Gondwanan margin from Turkey to New Zealand," in Early Palaeozoic Peri-Gondwana Terranes: New Insights From Tectonics and Biogeography, ed M. G. Bassett (London: Geological Society), 3-21. doi: 10.1144/SP325.2

Tran, H. T., Khin, Z., Halpin, J., Manaka, T., Meffre, S., Lai, C. K., et al. (2014). The Tam-Ky-Phuoc Shear Zone in central Vietnam. Tectonic and metallogenic implications. Gondwana Res. 26, 144-164. doi: 10.1016/j.gr.2013.04.008

Tri, T. V. (1977). Geology of Vietnam. Hanoi: Science and Technology Publishing House.

Tri, T. V., Faure, M., Nguyen, V. V., Bui, H. H., Bryl, M., Fyhne, W., et al. (2020). Neoproterozoic to Early Triassic tectono-stratigraphic evolution of Indochina and adjacent areas: a review with new data. J. Asian Earth Sci. 191:104231. doi: 10.1016/j.jseaes.2020.104231

Tri, T. V., and Vu, K. (2011). Geology and Earth Resources of Viet Nam. Hanoi: General Department of Geology and Minerals of Viet Nam.

Trung, N. M., Tsujimori, T., and Itaya, T. (2006). Honvang serpentinite body of the Song Ma fault zone, northern Vietnam: a remnant of oceanic lithosphere within the Indochina-South China suture. Gondwana Res. 9, 225-230. doi: 10.1016/j.gr.2005.06.012

Udchachon, M., Thassanapak, H., and Burrett, C. (2017). Palaeoenvironment and palaeogeography of Middle and Upper Devonian strata from the Loei fold belt, Indochina terrane (northeast Thailand). Palaeobiodiversity Palaeoenviron. 97, 497-516. doi: 10.1007/s12549-017-0294-Z

Udchachon, M., Thassanapak, H., and Burrett, C. (2018). Early Permian radiolarians from the extension of the Sa Kaeo Suture in Cambodia - tectonic implications. Geol. Magazine 155, 1449-1464. doi: $10.1017 /$ S0016756817000322

Udchachon, M., Thassanapak, H., Feng, Q., and Burrett, C. (2015). Palaeoenvironmental implications of geochemistry and radiolarians from Late Devonian chert/shale sequences of the Truong Son Foldbelt, Laos. Geol. J. 52, 154-173. doi: 10.1002/gj.2743

Ueno, S., and Charoentitirat, T. (2011). "Carboniferous to Permian” in The Geology of Thailand, eds M. F. Ridd, A. J. Barber, and M. J. Crow (London: Geological Society), 71-136. doi: 10.1144/GOTH.5

Uzuki, T., Lan, C., Wang, K., and Chiu, H. (2013). Linking the Indochina block and Gondwana during the Early Palaeozoic: evidence from U-Pb ages and $\mathrm{Hf}$ isotopes of detrital zircons. Tectonophysics 586, 145-159. doi: $10.1016 /$ j.tecto.2012.11.010

Vilayhack, S. (2010). “Geological mapping and mineral resources in Attapeu area," in Proceedings of the Thai-Lao Technical Conference on Geology and Mineral Resources, ed P. Puncharoen (Bangkok: Department of Mineral Resources).

Wang, Y., Wang, Y., Qian, X., Zhang, Y., Gan, C., Senebouttalath, V., et al. (2020). Early Paleozoic subduction in the Indochina interior: Revealed 
by Ordo-Silurian mafic-intermediate igneous rocks in South Laos. Lithos 2020:105488. doi: 10.1016/j.lithos.2020.105488

Wang, Z., Cao, D., Wang, Z., Wang, A., and Wu, Y. (2018). Zircon U-Pb age, trace element and $\mathrm{Hf}$ isotope composition of Sepon $\mathrm{Au}-\mathrm{Cu}$ deposit, Laos: tectonic and metallogenic implications. China Geol. 1, 36-48. doi: $10.31035 / \mathrm{cg} 2018006$

Xia, X., Jian, X., Huang, C., Long, X., and Zhou, M. (2020). Subduction polarity of the Ailaoshan Ocean (eastern Paleotethys): constraints from detrital zircon $\mathrm{U}-\mathrm{Pb}$ and Hf-O isotopes for the Longtan Formation. Bullet. Geol. Soc. Am. 132, 987-996. doi: 10.1130/B35294.1

Xia, X., Nie, X., Lai, C., Wang, Y., Long, X., and Meffre, S. (2016). Where was the Ailaoshan Ocean and when did it open: a perspective based on detrital zircon $\mathrm{U}-\mathrm{Pb}$ age and $\mathrm{Hf}$ isotope evidence. Gondwana Res. 36, 488-502. doi: 10.1016/j.gr.2015.08.006

Xu, J., Xia, X., Lai, C., Long, X., and Huang, C. (2019). When did the Paleotethys Ailaoshan Ocean close: new insights from detrital zircon $\mathrm{U}-\mathrm{Pb}$ age and $\mathrm{Hf}$ isotopes. Tectonics 38, 125-135. doi: 10.1029/2018TC005291

Xu, Y., Cawood, P. A., Du, Y., and Hu, L. (2017). Aulacogen formation in response to opening the Ailaoshan ocean: origin of the Qin-Fang Trough, South China. J. Geol. 125, 531-550. doi: 10.1086/693036

Yan, Y., Duan, L., Shumin, D., Wang, J., Huang, B., Zheng, W., et al. (2020). Paleomagnetic constraint on the Carboniferous paleoposition of Indochina and its implications for the evolution of eastern Paleo-Tethys Ocean. J. Geophys. Res. Solid Earth. 39:e2020TC006168, doi: 10.1029/2020TC006168

Yan, Y., Huang, B., Zhang, D., Charusiri, P., and Veeravinantanakul, A. (2018). Paleomagnetic study on the permian rocks of the indochina block and its implications for paleogeographic configuration and northward drifting of cathaysialand in the paleo-tethys. J. Geophys. Res. Solid Earth 123, 4523-4538. doi: 10.1029/2018JB015511

Young, G., and Lu J. (2020). Asia-Gondwana connections indicated by Devonian fishes from Australia: palaeogeographic considerations. J. Palaeogeogr. 9, 1-22. doi: $10.1186 /$ s42501-020-00057-x
Young, G. C., and Janvier, P. (1999). "Early-middle Palaeozoic vertebrate faunas in relation to Gondwana dispersion and Asian accretion," in Gondwana Dispersion and Asian Accretion, eds I. Metcalfe, J. S. Ren, J. Charvet, and S. Hada (Rotterdam: A. A. Balkema) IGCP 321, 115-140.

Zhang, R. Y., Lo, C. H., Chung, S. L., Grove, M., Omori, S., Iizuka, Y., et al. (2013). Origin and tectonic implication of ophiolite and eclogite in the Song Ma Suture Zone between the South China and Indochina blocks. J. Metamorphic Geol. 31, 49-62. doi: 10.1111/jmg. 12012

Zhao, T., Qian, X., and Feng, Q. (2016). Geochemistry, Zircon U-Pb age and Hf isotopic constraints on the petrogenesis of the Silurian rhyolites in the Loei fold belt and their tectonic implications. J. Earth Sci. 27, 391-402. doi: 10.1007/s12583-016-0671-y

Zhu, D., Zhao, Z., Niu, Y., Dilek, Y., and Mo, X. (2011). Lhasa terrane in southern Tibet came from Australia. Geology 39, 727-730. doi: 10.1130/G3 1895.1

Zi, J., Cawood, P., Fan, W., Wang,Y., Tohver, E., McCuig, T. M., et al. (2012). Triassic collision in the Paleo-Tethys constrained by volcanic activity in SW China. Lithos 144, 145-160. doi: 10.1016/j.lithos.2012. 04.020

Conflict of Interest: The authors declare that the research was conducted in the absence of any commercial or financial relationships that could be construed as a potential conflict of interest.

Copyright (C) 2021 Burrett, Udchachon and Thassanapak. This is an open-access article distributed under the terms of the Creative Commons Attribution License (CC $B Y)$. The use, distribution or reproduction in other forums is permitted, provided the original author(s) and the copyright owner(s) are credited and that the original publication in this journal is cited, in accordance with accepted academic practice. No use, distribution or reproduction is permitted which does not comply with these terms. 